\title{
Socialfaglig analyse
}

- processer, vidensformer \& perspektiver i myndighedsarbejdet på børne- og ungeområdet.

En forskningsoversigt.

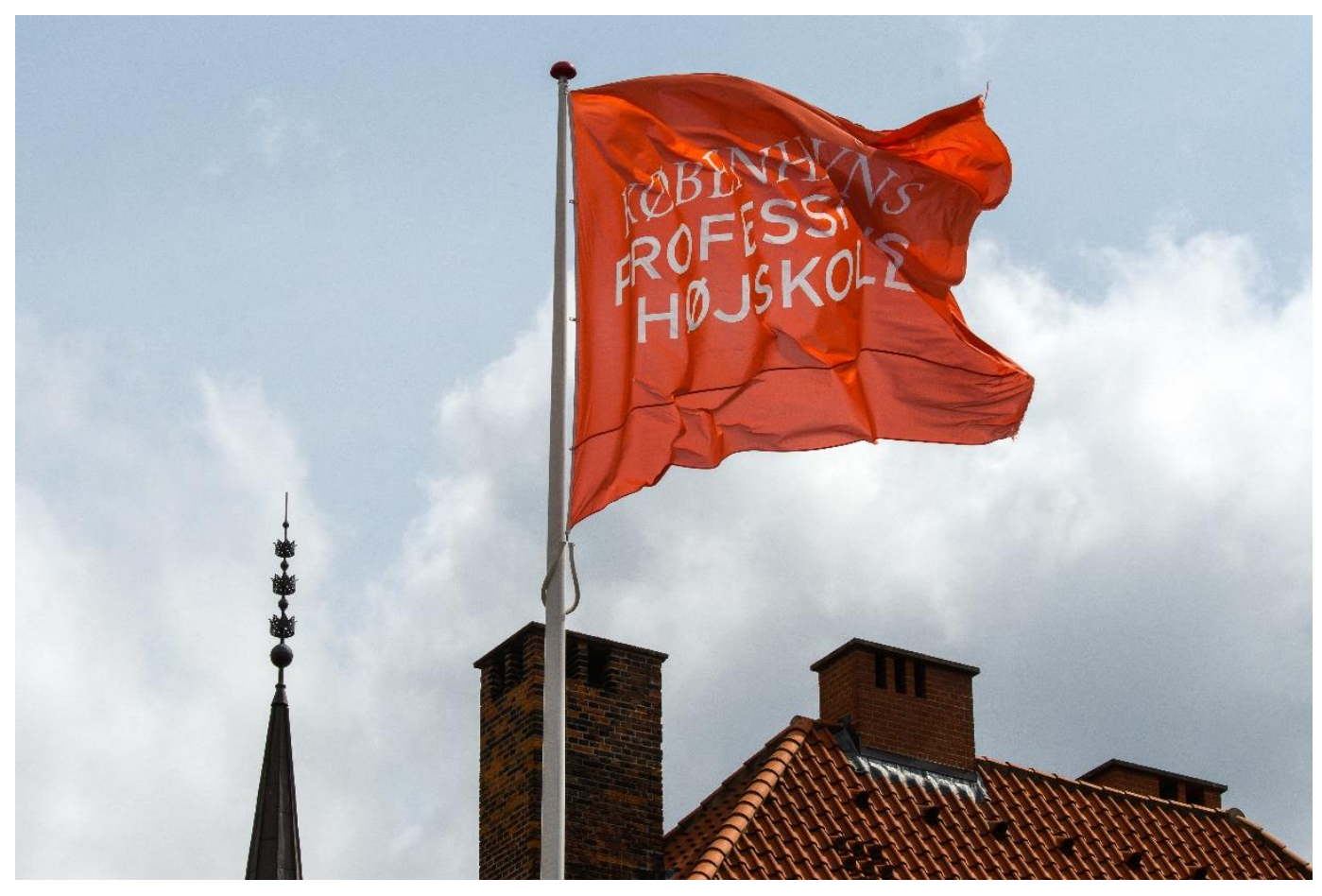

Annemette Matthiessen, Lotte Andersen \& Katrin Leicht Schnohr, januar 2022 


\section{Indholdsfortegnelse}

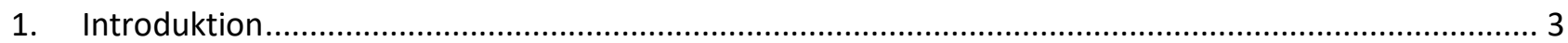

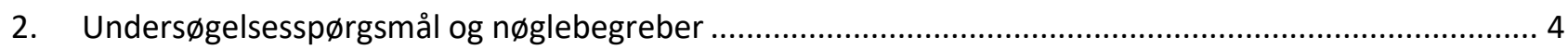

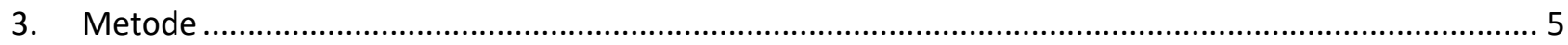

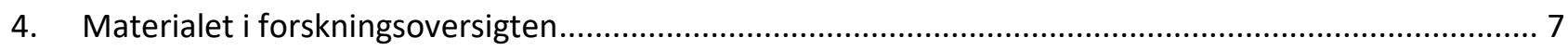

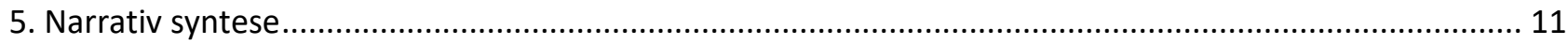

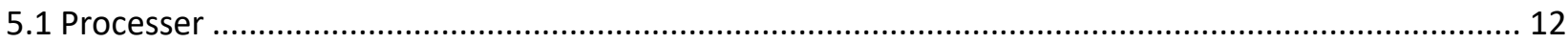

5.1.1 Hvordan kommer systematik til udtryk i den socialfaglige analyse? ......................................... 12

5.1.2 Hvordan kobler faserne beskrivelse, analyse og vurdering sig til den socialfaglige analyse?........ 17

5.1.3 Hvordan er sammenhængen mellem den socialfaglige analyse og en udviklingsstøttende proces

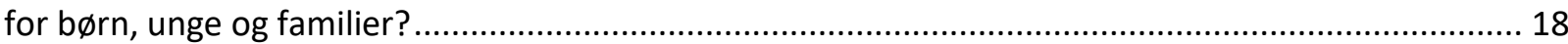

5.1.4 Indgår analysen som en afgrænset del af sagsforløbet eller som en kontinuerlig og foranderlig

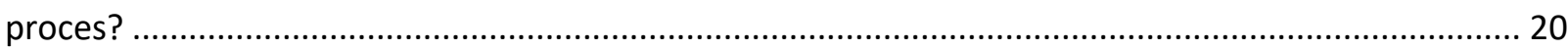

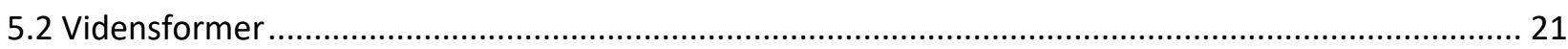

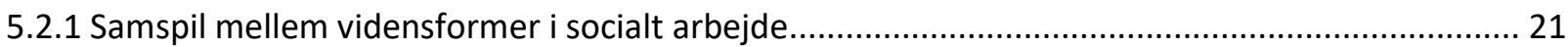

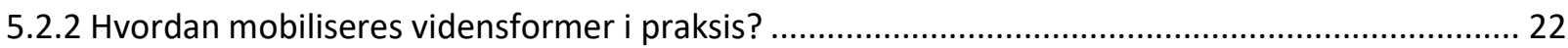

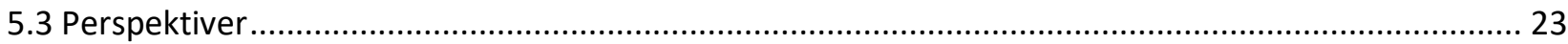

5.3.1 På hvilken måde indgår borgernes perspektiv som en del af analysen? .................................... 23

5.3.2 Hvilke faglige perspektiver anvender socialarbejderen i analysen og hvordan bruges de? .......... 26

5.3.4 På hvilken måde indgår socialarbejderens personlige perspektiv som en del af analysen?.......... 27

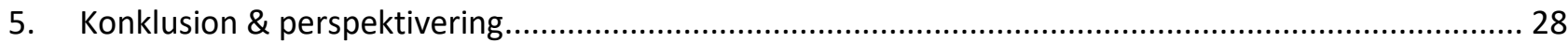

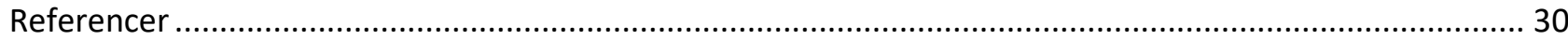




\section{Introduktion}

Dette dokument er en forskningsoversigt hvis formål er at skabe overblik over eksisterende viden om brug af socialfaglig analyse i myndighedsarbejde på børne- og ungeområdet.

Socialfaglig analyse og efterfølgende vurderinger og indstillinger indgår som en kernekompetence hos socialarbejdere på myndighedsområdet. Dette har Ankestyrelsen fastslået (Ankestyrelsen 2012). En socialfaglig analyse er fundamentet for en faglig kvalificeret vurdering og er dermed afsæt for begrundelsen af valgte indsatser. Derudover er socialfaglig analyse også rammesættende for det fremtidige handlegrundlag, når barnets eller den unges og familiens situation ændrer sig, og der senere skal følges op i sagen. Det er i den socialfaglige analyse, at man finder de vigtige mellemregninger mellem indsamlede informationer og beslutninger og afgørelser.

Socialfaglig analyse er i 2018 med betegnelsen 'faglig udredning' udpeget som et af fire pejlemærker for kvalitet i børne- og ungesager af Socialministeriet. De $\varnothing$ vrige tre pejlemærker er inddragelse, valg af indsats og opfølgning (Kvalitet i sagsbehandlingen 2018). Pejlemærkerne indgår bl.a. i Socialstyrelsens Task Force analyser og udviklingsforløb i kommuner og i Børnekatalogets ${ }^{1}$ kurser.

Forskningsoversigten er en del af et forsknings- og udviklingsprojekt; De vigtige mellemregninger - om brugen af socialfaglig analyse i myndighedsarbejdet på børne-og ungeområdet 2019-2022. Projektet er finansieret af Socialstyrelsen.

Det er projektets formål er at understøtte og kvalificere den analytiske tilgang hos socialarbejdere på myndighedsområdet for at styrke kvaliteten af socialfaglig analyse overfor målgruppen udsatte børn, unge og deres familier med en sag, der omfatter udredningsforløb i den kommunale forvaltning efter Servicelovens kapitel 11. For at kunne understøtte og kvalificere er det afgørende at kende til den eksisterende praksis blandt socialarbejdere. Med formuleringen fra projektets titel er formålet med forskningsoversigten at finde frem til i hvilken grad mellemregningerne kommer med i børn- og ungesager, om der er mellemregninger som er særlige vigtige og om der er mellemregninger som udelades?

Projektet har et sekventielt design, som består af fire dele. Forskningsoversigten bygger videre på et notat "Hvad er socialfaglig analyse? - svar fra et videreuddannelsesperspektiv" (Schnohr, Andersen \& Matthiessen 2020) og er udgangspunkt for vidensbaserede pointer om socialfaglig analyse i det videre projekt. Det sker dels i en faglig artikel i Uden for Nummer (Andersen, Schnohr \& Matthiessen 2021), som er et tidsskrift for praksis, udvikling og forskning i socialt arbejde, og dels via et materiale til undervisningen på grund- og videreuddannelsen af socialarbejdere på myndighedsområdet.

${ }^{1}$ Se mere om Task Forceforløb og $\underline{B \varnothing r n e k a t a l o g e t}$. 
Undersøgelsesdesignet kan illustreres som i figur 1:

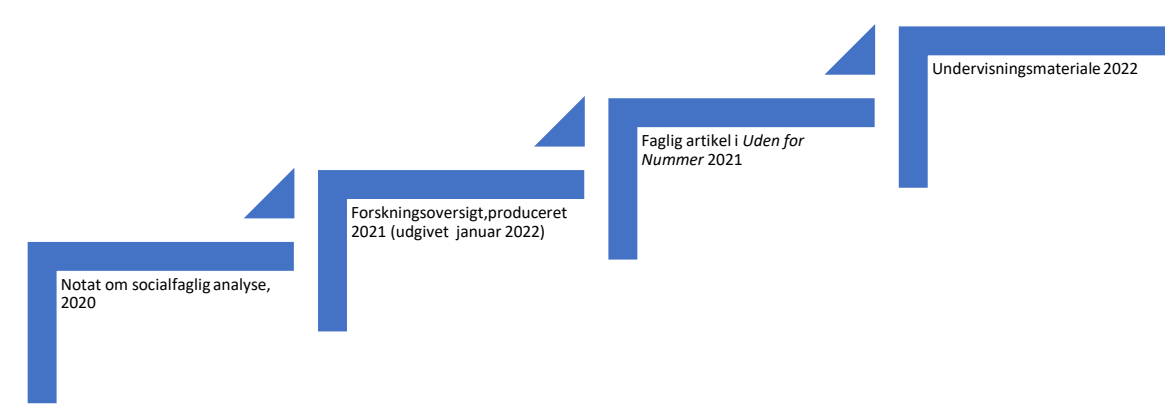

Figur 1: Projektets design

I notatet om socialfaglig analyse er der en operationalisering af begrebet socialfaglig analyse, som bygger på litteratur fra de professionsh øjskoler ${ }^{2}$, der på unders $\varnothing$ gelsestidspunktet udbød den sociale diplomuddannelse- børn og unge samt Aalborg Universitets Master i udsatte børn og unge. Litteraturen indgår i undervisningen af de studerende i socialfaglig sagsanalyse på videreuddannelse rettet mod socialarbejdere og ledere med myndighedsopgaver på børn- og ungeområdet.

Gennemgang af litteraturen viser, at størstedelen af tekster er fagbøger og lærebøger, som angiver hvordan sagsbehandleren kan eller $b ø r$ arbejde med socialfaglig analyse. Der refereres i begrænset omfang til unders $\emptyset$ gelser, der interesserer sig for, hvordan sagsbehandleren i praksis arbejder med socialfaglig analyse. Kun fire af i alt 14 undervisningstekster bygger direkte på primær eller sekundær forskning eller empiriske undersøgelser om socialfaglig analyse. Dette tyder på at litteraturen om socialfaglig analyse i nogen grad er dekoblet viden om socialfaglig analyse som praksis i børn- og ungearbejdet. Det styrker i vores øjne relevansen af en forskningskortlægning med overblik over eksisterende forskningsviden. I en kortlægning af danske undersøgelser fra VIVE peger forfatterne på, at der er ganske få publikationer om faglig udredning, men også at der et kommet et større fokus på den faglige udredning (Bengtsson \& Olsen 2021). En forskningskortlægning kan indgå i undervisningsforløb, så forestillinger om og ønsker til socialt myndighedsarbejde med børn og unge kan diskuteres op imod hvordan det sociale arbejde faktisk udfolder sig i praksis, og der kan bygges en bro mellem de to forskellige tilgange.

\section{Unders øgelsesspørgsmål og nøglebegreber}

Hovedspørgsmålet for forskningsoversigten er:

På hvilken måde arbejder socialarbejdere med socialfaglig analyse igennem

processer, vidensformer og perspektiver i børne- og ungesager?

Nøglebegreber i forskningsoversigten er 'Socialarbejder', 'Socialfaglig analyse' og 'Børne- og ungesager'.

En socialarbejder er i denne sammenhæng en fagprofessionel med et særligt myndighedsansvar, som agerer som offentlig forvalter af gældende lovgivning. En socialarbejder med myndighedsansvar træffer beslutninger og igangsætter indsatser (Moesby-Jensen \& Nielsen 2013; 81).

\footnotetext{
${ }^{2}$ Det drejer sig om Københavns Professionshøjskole, VIA, UCL og UCSyd.
} 
Ved socialfaglig analyse forstås de analytiske elementer som optræder i børne- og ungesager fra start til slut og særligt i den børnefaglige undersøgelse. Duncan Helm og Autumn Roesch-Marsh ser socialfaglige analyser som en kombination af faktisk information, teori, forskning og organisatoriske strukturer. Analysen formes af kontekst, kultur samt personlige og professionelle værdier (Helm \& Roesch-Marsh 2016).

En socialfaglig analyse indeholder både identitetsformende og koordinerende elementer. Identitetsformende fordi fortællinger og beskrivelser om os selv former den måde, vi forstår os selv på, og koordinerende, fordi analysen danner grundlag for det videre samarbejde mellem børn, unge, familie og netværk og de professionelle (Holmgren 2010, Bjerre 2017). De professionelle samarbejdspartnere omfatter især kolleger i myndighedsarbejdet, ledere og visitationsudvalg, tværprofessionelle samarbejdspartnere fra almen- og specialområdet bl.a. pædagoger, lærere og sundhedsplejersker samt tilsynsinstitutioner bl.a. Ankestyrelse og revision.

'Socialfaglig analyse' bruges i oversigten synonymt med faglig udredning. Vi har valgt at bruge termen socialfaglig analyse fremfor faglig udredning fordi det er det begreb mange socialarbejdere bruger om deres egen praksis.

En socialfaglig analyse kan ifølge operationaliseringen i notatet om socialfaglig analyse omfatte processer, vidensformer og perspektiver. En socialfaglig analyse er forskellig fra en akademisk analyse, fordi borgerens perspektiv indgår, den er i alle tilfælde ufuldstændig og der kan være tale om handletvang (Bjerre 2017, Schnohr, Andersen \& Matthiessen 2020).

Børne- og ungesager forstås som den interaktion, der knytter sig til kommunikation, beslutninger og afgørelser i et sagsforløb undervejs for de direkte involverede aktører, dvs. typisk socialarbejder og barnet eller den unge og forældre samt professionelt og privat netværk samt de journaler, som produceres $\mathrm{i}$ forvaltningen om sagen (Matthiessen, Zeeberg \& Haack 2017).

\section{Metode}

Forskningsoversigten er udformet som en narrativ syntese (Popay, Roberts, Sowden, Petticrew, Arai, Rodgers, Britten, Roen \& Duffy 2006). Den omfatter tre elementer:

1. En systematisk litteratursøgning i den betydning at der lavet en strategi for, hvordan litteratursøgningen skulle foregå,

2. En vurdering af den fundne litteraturs metodiske kvalitet,

3. En syntese af fundene i den fremsøgte litteratur.

Vi indledte med at udarbejde en protokol med et undersøgelsesspørgsmål og en strategi for hvordan vi ville gribe den systematiske litteraturs $\varnothing$ gning an. Unders $\varnothing$ gelsesspørgsmålet blev udformet med afsæt i operationaliseringen af socialfaglig analyse i notatet om socialfaglig analyse og med kvalificering af Stinna Vestergaard, tidligere videnskabelig assistent ved Dansk Clearinghouse for Uddannelsesforskning, DPU ${ }^{3}$. Stinna Vestergaard har særligt kvalificeret undersøgelsesspørgsmålet og inklusions- og eksklusionskriterier.

\footnotetext{
${ }^{3}$ Dansk Clearing House eksisterede i perioden 2008-2019 og var et landsdækkende center, som udarbejdede forskningsreviews. Vi havde indgået en aftale om sparring inden nedlæggelsen og det lykkedes at finde en vej til samarbejde i nye rammer.
} 
Litteraturs $\varnothing$ gningen er foretaget i fire databaser; Den danske forskningsdatabase, Idunn, Soclndex og Academic Search. Den danske forskningsdatabase og Idunn er valgt ud fra et $\emptyset$ nske om at finde artikler om unders $\emptyset$ gelser fra de nordiske lande, hvor velfærdsstats- og samfundsstrukturer ligner de danske. Soclndex er valgt som en central database inden for socialt arbejde og Academic Search efter råd fra Københavns Professionshøjskole informationsspecialist, Bente Larsen. Vi har desuden arbejdet med tre nyere danske ph.d'er, som drejer sig specifikt om myndighedsarbejdet i danske kommuner på børn- og ungeområdet (Møller 2018, Petersen 2017, Sørensen 2016) og dermed ligger tæt på vores undersøgelsesspørgsmål.

Det ville styrke kvaliteten af forskningsoversigten, hvis den var baseret på søgning i flere databaser. Erfaring viser imidlertid at 20-25 gode artikler og tilsvarende materialer kan være tilstrækkeligt grundlag for at afdække viden på et særligt område (personlig dialog med Beth Longley fra NatCen i UK, oktober 2014). Vi arbejder med 26 ph.d.'er og artikler i denne forskningsoversigt og ligger dermed tæt på det foreslåede antal.

Søgning, screening og sortering er foregået ved:

- Identificering af emneord på relevante søgedatabaser, som er databasernes identificeringer af hovedtemaer,

- Sortering på grundlag af titel, emneord og abstract på de 50-60 øverste referencer på hver af søgedatabaserne. Sorteringen er sket i samarbejde mellem mindst to af projektets deltagere,

- Sortering på baggrund af fuldtekstlæsning af en projektdeltager.

Vi har afgrænset os til unders $\varnothing$ gelser fra OECD-lande på dansk, svensk, norsk og engelsk og fra år 2010 til i dag. Vi er interesserede i unders $\varnothing$ gelser, der drejer sig om socialarbejderes sociale arbejde med udsatte børn og unge inden for en velfærdsstatsmodel, enten en universel-, en residual- eller en korporativ. Den universelle model er præget af høje skatteprocenter, universelle velfærdsydelser og en omfattende omfordeling og modellen forbindes med de nordiske lande, hvor den residuale velfærdsmodel knyttes til de angelsaksiske lande og er karakteriseret ved forholdsvis lave skattesatser og velfærdsydelser, som kun tildeles de fattigste. I den korporative velfærdsstatsmodel har arbejdsmarkedstilknytning og familien og civilsamfundet en central betydning. Staten indgår i et tæt samarbejde med virksomhederne (Esping-Andersen 1990). Kriteriet er begrundet i, at vi ønsker at afgrænse os til lande, hvor staten leverer, finansierer og organiserer en grad af velfærd i forhold til udsatte børn og unge og som ansætter uddannede socialarbejdere til at udføre myndighedsopgaver på børne- og ungeområdet. De nordiske lande er med deres universelle velfærdsstatsmodeller tættest på danske forhold, men undersøgelser fra andre OECDlande kan være relevante med opmærksomhed på de forskelle der er på bl.a. velfærdsstatstype, velfærdsindsatser og sagsbehandleres uddannelsesmæssige baggrund.

Eksklusionskriterier er artikler om socialt arbejde, som ikke relaterer sig til myndighedssagsarbejdet, ikke omfatter empirisk forskning og ikke er peer-reviewed og/eller har eksplicitte undersøgelsesspørgsmål og metodeafsnit. Vi ønsker primært originale forskningsartikler eller vidensopsamlinger til socialarbejdere med et tydeligt afsæt i empiriske undersøgelser. 
Emneordene fremgår af tabel 1:

\begin{tabular}{|l|l|l|}
\hline \multicolumn{1}{|c|}{$\begin{array}{c}\text { Socialarbejder på } \\
\text { myndighedsområdet }\end{array}$} & \multicolumn{1}{c|}{ Bocialfaglig analyse } \\
\hline \multicolumn{1}{|c|}{ Dansk } \\
\hline Fagprofessionel & Børnefaglig unders $\varnothing$ gelse & Sagsakter \\
\hline Socialarbejder & Systematisk sagsarbejde & Journaler \\
\hline Myndighedssagsbehandler & Faglig udredning & \\
\hline Rådgiver & & \\
\hline Praktiker & & \\
\hline Myndighedsud $\varnothing v e r$ & Assessment & Child welfare \\
\hline Casework & Assessment of client needs & Social care analysis \\
\hline Social Work & Risk assessment & Child care \\
\hline Social service & Outcome assessment & Child protection \\
\hline Personel social service & Intervention & Statutory social work \\
\hline Social case work & Deliberation & Public welfare \\
\hline Social service case management & & \\
\hline Child welfare work & & \\
\hline
\end{tabular}

Tabel 1: Emneord på dansk og engelsk til databasesøgning

\section{Materialet i forskningsoversigten}

Vores søgning af litteratur resulterede i 29 materialer, som omfatter tre nyere danske ph.d'er og 26 artikler. Materialerne blev fordelt mellem projektets tre deltagere, fuldtekstlæst og bearbejdet via en fælles skabelon med spørgsmål om socialfaglig analyse og det metodiske grundlag. Vi frasorterede tre artikler på baggrund af eksklusionskriterierne, og de øvrige 26 blev vurderet efter relevans på en skala fra 1-5, hvor 1 er den laveste og 5 den højeste vurdering. I tabel 2 er der en oversigt over materiale opdelt på lande og i alfabetisk rækkefølge efter forfattere. Det fremgår at kun fire materialer er fra Danmark og heraf er de tre fundet uafhængigt af den systematiske litteraturs $\varnothing$ gning, fem er fra Sverige og Norge, mens over halvdelen af artiklerne præsenterer empiriske undersøgelser fra Storbritannien. Dette kan være en afspejling af at forskning i socialt arbejde er et relativt nyt felt i Danmark sammenlignet med andre lande bl.a. England (Olesen, Eskelinen \& Caswell 2005) og understøtter, at der er behov for yderligere viden om socialfaglig analyse i en dansk kontekst. 


\begin{tabular}{|c|c|c|c|c|c|c|}
\hline Nr. & Titel & Forfattere & Unders $\varnothing$ gelsesdesign & Årstal & $\begin{array}{l}\text { Land/ } \\
\text { område }\end{array}$ & $1-5$ \\
\hline \multicolumn{7}{|c|}{ DANMARK } \\
\hline 1 & $\begin{array}{l}\text { Den børnefaglige } \\
\text { unders } \varnothing \text { gelse - på } \\
\text { vej med } \\
\text { handleplanen }\end{array}$ & $\begin{array}{l}\text { Kildedal, } \\
\text { Uggerh } \varnothing \text { j, } \\
\text { Nordstoga \& } \\
\text { Sagatun }\end{array}$ & $\begin{array}{l}\text { Kvalitative } \\
\text { casestudier }\end{array}$ & 2010 & $\begin{array}{l}\text { DK og } \\
\text { Norge }\end{array}$ & 3 \\
\hline 2 & $\begin{array}{l}\text { Organizing } \\
\text { knowledge and } \\
\text { decision making in } \\
\text { street-level } \\
\text { professional practice }\end{array}$ & Møller & $\begin{array}{l}\text { Etnografiske } \\
\text { metoder, } \\
\text { mixed methods }\end{array}$ & 2018 & DK & 5 \\
\hline 3 & $\begin{array}{l}\text { At unders } \varnothing \text { ge og } \\
\text { blive unders } \varnothing \mathrm{gt}\end{array}$ & Petersen & $\begin{array}{l}\text { Kvalitative } \\
\text { casestudier }\end{array}$ & 2017 & DK & 4 \\
\hline 4 & $\begin{array}{l}\text { Metoder til den } \\
\text { børnefaglige } \\
\text { undersøgelse i } \\
\text { komparativt } \\
\text { perspektiv (består af } \\
\text { en kappe og tre } \\
\text { artikler) }\end{array}$ & Sørensen & Mixed methods & 2016 & DK & 4 \\
\hline \multicolumn{7}{|c|}{ SVERIGE \& NORGE } \\
\hline 5 & $\begin{array}{l}\text { Searching for the } \\
\text { right track - } \\
\text { managing care } \\
\text { trajectories in child } \\
\text { welfare }\end{array}$ & $\begin{array}{l}\text { Enell \& } \\
\text { Denvall }\end{array}$ & $\begin{array}{l}\text { Kvalitative } \\
\text { casestudier }\end{array}$ & 2017 & Sverige & 3 \\
\hline 6 & $\begin{array}{l}\text { Decision-making in } \\
\text { child welfare } \\
\text { services: } \\
\text { Professional } \\
\text { discretion versus } \\
\text { standardized } \\
\text { templates }\end{array}$ & $\begin{array}{l}\text { Heggdalsvik, } \\
\text { Rød \& } \\
\text { Heggen }\end{array}$ & $\begin{array}{l}\text { Tværsnitsstudier/fok } \\
\text { usgruppeinterview }\end{array}$ & 2018 & Norge & 3 \\
\hline 7 & $\begin{array}{l}\text { Colligation in child } \\
\text { welfare work: } \\
\text { Decision making in a } \\
\text { case on the tipping } \\
\text { point }\end{array}$ & Skotte & $\begin{array}{l}\text { Kvalitative } \\
\text { casestudier }\end{array}$ & 2016 & Norge & 3 \\
\hline 8 & $\begin{array}{l}\text { On caseworkers } \\
\text { writing in child } \\
\text { welfare when less is } \\
\text { more }\end{array}$ & Skotte & $\begin{array}{l}\text { Kvalitative } \\
\text { casestudier }\end{array}$ & 2020 & Norge & 2 \\
\hline
\end{tabular}




\begin{tabular}{|c|c|c|c|c|c|c|}
\hline Nr. & Titel & Forfattere & Undersøgelsesdesign & Årstal & $\begin{array}{l}\text { Land/ } \\
\text { område }\end{array}$ & $1-5$ \\
\hline \multicolumn{6}{|c|}{ STORBRITANNIEN (SB) } & \\
\hline 9 & $\begin{array}{l}\text { Contextualisering } \\
\text { case reviews: A } \\
\text { methodology for } \\
\text { developing systemic } \\
\text { safeguarding } \\
\text { practices }\end{array}$ & Firmin & $\begin{array}{l}\text { Serious case review } \\
\text { (SCR) }\end{array}$ & 2018 & $\begin{array}{l}\text { Storbrita } \\
\text { nnien } \\
\text { (SB) } \\
\text { (England } \\
\text { ) }\end{array}$ & 1 \\
\hline 10 & $\begin{array}{l}\text { Outcomes in } \\
\text { Children's Social } \\
\text { Care }\end{array}$ & Forrester & Tværsnitsstudier & 2017 & SB & 2 \\
\hline 11 & $\begin{array}{l}\text { The Ecology of } \\
\text { Judgement: A Model } \\
\text { for } \\
\text { Understanding and } \\
\text { Improving Social } \\
\text { Work Judgements }\end{array}$ & $\begin{array}{l}\text { Helm \& } \\
\text { Roesch- } \\
\text { Marsh }\end{array}$ & $\begin{array}{l}\text { Præsentation af en } \\
\text { model til } \\
\text { forståelse og } \\
\text { forbedring af } \\
\text { beslutningsprocesser } \\
\text { baseret på } \\
\text { artikelgennemgang }\end{array}$ & 2016 & SB & 4 \\
\hline 12 & $\begin{array}{l}\text { Why parents matter: } \\
\text { exploring the impact } \\
\text { of a hegemonic } \\
\text { concern with the } \\
\text { timetable for } \\
\text { children }\end{array}$ & Holt \& Kelly & $\begin{array}{l}\text { Metaanalyse baseret } \\
\text { på sekundær empiri } \\
\text { og udviklingen i love } \\
\text { og regler }\end{array}$ & 2013 & SB & 3 \\
\hline 13 & $\begin{array}{l}\text { How Professionals } \\
\text { Experience } \\
\text { Complexity: An } \\
\text { interpretative } \\
\text { Phenomenological } \\
\text { Analysis }\end{array}$ & Hood & $\begin{array}{l}\text { Kvalitative } \\
\text { casestudier }\end{array}$ & 2014 & $\begin{array}{l}\text { SB } \\
\text { (England } \\
\text { ) }\end{array}$ & 1 \\
\hline 14 & $\begin{array}{l}\text { Revisiting the Rule } \\
\text { of Optimism }\end{array}$ & $\begin{array}{l}\text { Kettle \& } \\
\text { Jackson }\end{array}$ & $\begin{array}{l}\text { Serious case reviews } \\
\text { (SCR) }\end{array}$ & 2017 & SB & 1 \\
\hline 15 & $\begin{array}{l}\text { The tipping point: } \\
\text { Fateful moments in } \\
\text { child protection }\end{array}$ & Kettle & $\begin{array}{l}\text { Kvalitative } \\
\text { casestudier }\end{array}$ & 2017 & $\begin{array}{l}\text { SB } \\
\text { (Skotlan } \\
\text { d) }\end{array}$ & 2 \\
\hline 16 & $\begin{array}{l}\text { The assembly of } \\
\text { active participation } \\
\text { by parents of } \\
\text { children subject to a } \\
\text { multi-agency model } \\
\text { of early intervention }\end{array}$ & Lucas & $\begin{array}{l}\text { Kvalitative } \\
\text { casestudier }\end{array}$ & 2019 & $\begin{array}{l}\text { SB } \\
\text { (England } \\
\text { ) }\end{array}$ & 3 \\
\hline
\end{tabular}




\begin{tabular}{|c|c|c|c|c|c|c|}
\hline Nr. & Titel & Forfattere & Unders $\varnothing$ gelsesdesign & Årstal & $\begin{array}{l}\text { Land/ } \\
\text { område }\end{array}$ & $1-5$ \\
\hline 17 & $\begin{array}{l}\text { Assessing Parental } \\
\text { Capacity when there } \\
\text { are Concerns about } \\
\text { an Unborn Child }\end{array}$ & $\begin{array}{l}\text { Lusley, } \\
\text { Barlow, } \\
\text { Rayns \& } \\
\text { Ward }\end{array}$ & Tværsnitsstudier & 2017 & SB & 3 \\
\hline 18 & $\begin{array}{l}\text { Social work, poverty } \\
\text { and child welfare } \\
\text { interventions }\end{array}$ & $\begin{array}{l}\text { Morris, } \\
\text { Mason, } \\
\text { Bywaters, } \\
\text { Featherstone, } \\
\text { Brady, } \\
\text { Bunting, } \\
\text { Hooper, } \\
\text { Mirza, } \\
\text { Scourfield \& } \\
\text { Webb }\end{array}$ & Mixed methods & 2018 & $\begin{array}{l}\text { SB } \\
\text { (England } \\
+ \\
\text { Skotland } \\
\text { ) }\end{array}$ & 3 \\
\hline 19 & $\begin{array}{l}\text { Child protection } \\
\text { decision-making: } \\
\text { Social workers } \\
\text { perceptions }\end{array}$ & Nhlanganiso & $\begin{array}{l}\text { Kvalitative } \\
\text { casestudier }\end{array}$ & 2018 & $\begin{array}{l}\text { SB } \\
\text { (England } \\
\text { ) }\end{array}$ & 2 \\
\hline 20 & $\begin{array}{l}\text { A study of serious } \\
\text { case reviews } \\
\text { between } 2016 \text { and } \\
\text { 2018: what are the } \\
\text { key barriers doe } \\
\text { social workers in } \\
\text { identifying and } \\
\text { responding to child } \\
\text { neglect? }\end{array}$ & $\begin{array}{l}\text { Solem, Diaz \& } \\
\text { Hill }\end{array}$ & $\begin{array}{l}\text { Kvalitative } \\
\text { casestudier }\end{array}$ & 2019 & $\begin{array}{l}\text { SB } \\
\text { (England } \\
\text { ) }\end{array}$ & 3 \\
\hline 21 & $\begin{array}{l}\text { Adverse Childhood } \\
\text { Experiences: Beyond } \\
\text { Signs of Safety; } \\
\text { Reimagining } \\
\text { the Organisation and } \\
\text { Practice of Social } \\
\text { Work with Children } \\
\text { and Families }\end{array}$ & $\begin{array}{l}\text { Spratt, } \\
\text { Devaney \& } \\
\text { Frederick }\end{array}$ & $\begin{array}{l}\text { Data fra eksisterende } \\
\text { kvalitative og } \\
\text { kvantitative } \\
\text { undersøgelser }\end{array}$ & 2019 & SB & 1 \\
\hline 22 & $\begin{array}{l}\text { What makes it so } \\
\text { hard to look and to } \\
\text { listen? }\end{array}$ & $\begin{array}{l}\text { Turney \& } \\
\text { Ruch }\end{array}$ & Aktionsforskning & 2018 & SB & 2 \\
\hline 23 & $\begin{array}{l}\text { How do you solve a } \\
\text { problem like Maria? } \\
\text { Family complexity } \\
\text { and institutional } \\
\text { complications in UK } \\
\text { social work }\end{array}$ & $\begin{array}{l}\text { Walsh, } \\
\text { Morris \& } \\
\text { Doherty }\end{array}$ & $\begin{array}{l}\text { Fokusgruppeintervie } \\
\mathrm{w}\end{array}$ & 2018 & SB & 3 \\
\hline
\end{tabular}




\begin{tabular}{|c|c|c|c|c|c|c|}
\hline Nr. & Titel & Forfattere & Undersøgelsesdesign & Årstal & $\begin{array}{l}\text { Land/ } \\
\text { område }\end{array}$ & $1-5$ \\
\hline \multicolumn{7}{|c|}{ KOMPARATIVE UNDERS $\varnothing$ GELSER OG ANDRE LANDE } \\
\hline 24 & $\begin{array}{l}\text { Using qualitative } \\
\text { data-mining to } \\
\text { identify skillfull } \\
\text { practice in child } \\
\text { welfare case reds }\end{array}$ & $\begin{array}{l}\text { Carnochan, } \\
\text { Weissinger, } \\
\text { Henry, Liner- } \\
\text { Jigamian \& } \\
\text { Austin }\end{array}$ & $\begin{array}{l}\text { Kvalitativ } \\
\text { sagsgennemgang }\end{array}$ & 2018 & USA & 1 \\
\hline 25 & $\begin{array}{l}\text { Child protection } \\
\text { systems between } \\
\text { professional } \\
\text { cooperation and } \\
\text { trustful relationship: } \\
\text { A comparison of } \\
\text { professional } \\
\text { practical and ethical } \\
\text { dilemmas in } \\
\text { England/Wales, } \\
\text { Germany, Portugal } \\
\text { and Slovenia }\end{array}$ & $\begin{array}{l}\text { Meysen \& } \\
\text { Kelly }\end{array}$ & $\begin{array}{l}\text { Narrative } \\
\text { fokusgruppeintervie } \\
\text { ws opdelt på lande }\end{array}$ & 2018 & $\begin{array}{l}\text { England/ } \\
\text { Wales, } \\
\text { Tyskland, } \\
\text { Portugal } \\
\text { og } \\
\text { Slovenie } \\
\mathrm{n}\end{array}$ & 1 \\
\hline 26 & $\begin{array}{l}\text { Risk Assessment and } \\
\text { domestic violence - } \\
\text { how do child welfare } \\
\text { workers in three } \\
\text { countries assess and } \\
\text { substantiate the risk } \\
\text { level of 5-year-old } \\
\text { girl? }\end{array}$ & $\begin{array}{l}\text { Skivenes \& } \\
\text { Stenberg }\end{array}$ & Vignetunders $\varnothing$ gelse & 2015 & $\begin{array}{l}\text { Norge, } \\
\text { England } \\
\text { og } \\
\text { Californi } \\
\text { en }\end{array}$ & 3 \\
\hline
\end{tabular}

Tabel 2: Overblik over forskningsoversigtens materiale fordelt på lande i alfabetisk rækkefølge efter forfattere.

\section{Narrativ syntese}

Den valgte litteratur i forskningsoversigten er grundlaget for en narrativ syntese, hvor vi udvælger, gengiver og sammenholder forskningsfund og -resultater.

Syntesen er opdelt i tre tematiske områder; processer, vidensformer og perspektiver, som tilsammen dækker operationaliseringen af socialfaglig analyse og nedenfor er udmøntet i otte underspørgsmål på baggrund af notatet om socialfaglig analyse (Schnohr, Andersen \& Matthiessen 2020).

\section{Processer}

- Hvordan kommer systematik til udtryk i socialfaglige analyser?

- Hvordan kobler faserne beskrivelse, analyse og vurdering sig til socialfaglige analyser?

- Hvordan er sammenhængen mellem socialfaglig analyse og udviklingsstøttende processer for børn, unge og familier og netværk? 
- Indgår analysen primært som en afgrænset del af sagsforløbet eller mere som en kontinuerlig og foranderlig proces?

\section{Vidensformer}

- Hvilke vidensformer anvender socialarbejderne i den socialfaglige analyse og hvordan mobiliseres de i praksis?

\section{Perspektiver}

- På hvilken måde indgår borgernes perspektiv som en del af analysen? Er der en forskel på børne- og ungeperspektiver og forældre/netværksperspektiver?

- Hvilke faglige perspektiver anvender socialarbejderne i analysen og hvordan bruges de?

- På hvilken måde indgår socialarbejdernes personlige perspektiv som en del af analysen?

Nedenfor vil vi gennemgå fund og resultater i forskningsoversigtens artikler og ph.d'er og efter hvert delafsnit lave en opsummering. De unders $\varnothing$ gelser som vi refererer til fra artikler og ph.d'er præsenteres kort fagligt og metodisk første gang de nævnes og derefter fremgår de ved gængse litteraturreferencer.

\subsection{Processer}

\subsubsection{Hvordan kommer systematik til udtryk i den socialfaglige analyse?}

Systematik kan forstås på forskellige måder. I notatet om socialfaglig analyse ser forfatterne til lærebøger både systematik som en struktur, en refleksiv proces og en metode og som kombinationer af de tre elementer (Schnohr, Andersen \& Matthiessen 2020). I materialet til forskningsoversigten er det særligt to aspekter af systematik i sagsarbejdet, som opmærksomheden samler sig om. Det ene er betydningen af fælles skabeloner i børne- og ungesagsarbejdet, dvs. en form for struktur, og det andet om socialfaglige analyser indgår i individuelle eller kollektive processer på arbejdspladserne, som relaterer sig til metodiske og refleksive processer.

\subsubsection{Fælles struktur og standarder}

Skøn og fælles redskaber - alternativer eller gensidigt underst $\varnothing t$ ttende?

Skivenes \& Stenberg har unders $\varnothing$ gt brugen af fælles redskaber i opgaven med risikovurderinger blandt socialarbejdere fra tre lande, som repræsenterer forskellige velfærdssystemer (Skivenes \& Stenberg 2015). I Norge har socialarbejdere en familieorienteret tilgang, og de anvender ikke en bestemt metode eller bestemte redskaber. Den enkelte socialarbejder har en høj grad af autonomi. I USA er der til forskel fra dette en børnecentreret tilgang, hvor socialarbejderne bruger faste afkrydsningsskemaer, der er udviklet med afsæt i forskning om risiko- og beskyttelsesfaktorer. I England er der en blanding af de to systemer med et træk mod en børnecenteret tilgang og brug af en fast systematik. Risikovurderingerne er unders $\varnothing \mathrm{gt}$ via en vignet $i$ en survey med 301 deltagere fordelt mellem de tre lande. Et umiddelbart overraskende resultat i undersøgelsen er, at de norske socialarbejdere, som ikke bruger specifikke metoder eller redskaber i deres arbejde, har en højere grad af konsensus i deres vurdering af risikofaktorer end de amerikanske og engelske socialarbejdere, hvis guidelines burde strømline deres vurdering og understøtte en ensartet vurdering overfor børn, unge og familier. En forklaring på at de norske socialarbejdere når frem til overensstemmende risikovurderinger trods, at de ikke bruger fælles metoder og redskaber, kan være at de har udviklet og vedligeholdt et fagligt miljø og en professionsorientering, så der sker en normmæssig tilpasning. Dette forhold indgår ikke i unders $\varnothing$ gelsen, men Heggdalsvik, Rød \& Heggen fremhæver fra en anden unders $\varnothing$ gelse, at der en tradition i Norge for en skønsmæssig tilgang baseret på uddannelse 
(Heggdalsvik, Rød \& Heggen 2018). En sådan fælles forståelse og vurdering blandt socialarbejdere kan ses som en anden måde at arbejde med systematik på.

Heggdalsvik, Rød \& Heggen sammenligner beslutnings- og vurderingsprocesser på tre forskellige arbejdspladser i Norge gennem fokusgruppeinterviews med 36 socialarbejdere. På den ene arbejdsplads bruger socialarbejderne en standardiseret skabelon i beslutningsprocesserne, mens der på de øvrige to arbejdspladser udelukkende bruges en skønsmæssig tilgang. Sammenligningen viser, at der er variation i beslutningsprocesserne, men at de endelige beslutninger er næsten identiske (Heggdalsvik, Rød \& Heggen 2018). Så også denne unders $\emptyset$ gelse peger på, at fælles skabeloner er en af flere veje til systematik i sagsarbejdet.

\section{Standarder som vurderingsredskab}

En gruppe engelske forskere lægger til forskel fra fundene blandt norske socialarbejdere stor vægt på betydningen af fælles redskaber til at skabe systematik i en unders $\emptyset$ gelse af børnesager om omsorgssvigt (Solem, Diaz \& Hill 2019). Sagerne indgår i The national serious case review (SCR) i Storbritannien. SCR er retrospektive unders $\varnothing$ gelser af børnesager med mistanke eller viden om at misbrug eller omsorgssvigt har ført til, at et barn eller en ung er blevet alvorligt skadet eller er afgået ved døden (Firmin 2018). I halvdelen af 86 unders $\varnothing$ gte sager undervurderede socialarbejderne omfanget af omsorgssvigt. Forskerne peger på, at sagerne bygger på socialarbejdernes individuelle og normative vurderinger, som i nogle tilfælde er påvirket af lokalmiljøet og en normalisering af de vilkår, som socialarbejderne møder der. Der er fx sager, hvor socialarbejdere beskriver børn som går i børnehave og de tidligste klasser i skolen ved, at de har udviklet resiliens, selvstændighed og kan tage vare på sig selv, på trods af at de fleste professionelle vil mene at denne opgave er for krævende til børn i den alder (se fx de aldersopdelte fokusområder 2018). Forfatterne argumenterer for at et fælles redskab kan bruges komplementært til socialarbejdernes vurderinger og være en støtte i sager om omsorgssvigt, hvor det kan være svært at indfange konkrete udtryk for omsorgssvigt, men hvor der er kumulative virkninger hos barnet (Solem, Diaz \& Hill 2019).

Lushey, Barlow, Rayns \& Wars har i tråd med dette undersøgt, hvordan socialarbejdere håndterer unders $\varnothing$ gelser af ufødte børn i risiko for omsorgssvigt. De har interviewet 22 fagprofessionelle bl.a. socialarbejdere, jordem ødre og psykiatere fra ni forskellige lokalområder samt lavet en dokumentanalyse. Forskerne argumenterer for at der kan være særlige udfordringer i undersøgelser om ufødte børn bl.a. tvivl om barnet faktisk kommer til verden, og at det kan forsinke og forringe unders $\varnothing$ gelser af ufødte børns udviklingsbetingelser samt medføre, at forældrene til det ufødte barn får utilstrækkelig hjælp i graviditetsperioden. De anbefaler derfor, at der udvikles undersøgelsesværktøjer med særligt fokus på unders $\varnothing$ gelse af ufødte børn (Lushey, Barlow, Rayns \& Wars 2017).

Der kan være flere forklaringer på unders $\varnothing$ gelsernes forskellige vurdering af nytten af redskaber $\mathrm{i}$ myndighedsarbejdet. En forklaring kan være, at Skivenes \& Stenbergs vignetunders $\varnothing$ gelse drejer sig om vold, hvor det er åbenlyst, at der må gøres noget sammenlignet med SCR-undersøgelsen om omsorgssvigt, som virker langsomt over længere sigt. En anden forklaring kan være, at de engelske socialarbejdere har ringere arbejdsvilkår end deres norske kolleger og derfor ikke har samme mulighed for en professionsudvikling og vedligeholdelse af en fælles systematik ad den vej. Dette er ikke en forklaring som fremgår af unders $\varnothing$ gelserne, men vores hypotese, som Solem, Diaz \& Hill underbygger ved at pege på et stor arbejdspres i de engelske distrikter ${ }^{4}$ og mangel på tid og ressourcer (Solem, Diaz \& Hill 2019).

\footnotetext{
${ }^{4}$ Distrikter i England er det lokale myndighedsniveau og svarer til danske kommuner.
} 
Pointen om at socialarbejdere vænner sig til forhold i familierne i det specifikke lokalmiljø går igen hos i en multimetodisk unders $\varnothing$ gelse af sammenhængen mellem socialt arbejde, fattigdom og indsatser i børn- og ungearbejdet. Her peger forfatterne på at socialarbejdere i fattige områder i England og Skotland ser fattigdommen som for svær at gøre noget ved og for velkendt til at den bemærkes. Selv om socialarbejderne har viden om sammenhængen mellem fattigdom og omsorgssvigt, omsættes den ikke i konkrete sagsforl $\emptyset b$, da der er begrænsede handlemuligheder. Med andre ord fors $\varnothing$ ger socialarbejderne at håndtere individuelle risici dekoblet fra socioøkonomiske vilkår (Morris, Mason, Bywaters, Featherstone, Daniel, Brady, Bunting, Hooper, Mirza, Scourfield \& Webb 2018).

Både de engelske og de norske forskere anbefaler på baggrund af deres undersøgelser brug af en kombination af standardiserede redskaber og professionelt skøn i arbejdet med børne- og ungesager (Solem, Diaz \& Hill 2019; Heggdalsvik, Rød \& Heggen 2018). Heggdalsvik, Rød \& Heggen fremhæver ligesom de engelske forskere at en fordel ved standardiserede skabeloner er at de kan hjælpe socialarbejdere til at få øje på vigtige aspekter i en sag, men de tilføjer samtidig, at det er afgørende samtidig at arbejde skønsmæssigt med det unikke i hver sag. På baggrund af bl.a. interviews med 21 afdelingsledere og socialarbejdere fra seks danske kommuner når Kresta M. Sørensen frem til en lignende anbefaling. Et fund $\mathrm{i}$ hendes ph.d. er, at det ikke er begrænsende i sig selv at have en struktur at støtte sig til, men det er nødvendigt med frihed til at tolke retningslinjerne således at de kan tilpasses den enkelte borgers forhold. Unders $\emptyset$ gelsen peger desuden på at socialarbejderne gerne vil have retningslinjer og modeller at arbejde ud fra (Sørensen 2016b, 2016c). Nyathi henviser i denne sammenhæng til den danske forsker Matilde Høybye Mortensen, som er nået frem til at redskaber til st $\varnothing t t e$ af beslutningstagning har en tendens til at give et større skønsmæssigt rum til den fagprofessionelle, hvis de er teoretisk funderede (Mortensen $2013 \mathrm{i}$ Nyathi 2018).

\section{Implementering af fælles standarder}

Anne Mette Møller har unders $\varnothing$ gt organisering af videns- og beslutningsprocesser i Herning kommune og Københavns kommune via etnografiske metoder som omfatter personlige interviews med centrale aktører nationalt bl.a. fra Socialstyrelsen og Socialchefforeningen samt ledere, teamkoordinatorer, socialarbejdere og andre fagprofessionelle i kommunerne kombineret med feltarbejde og dokumentanalyse. Selv om Møller ikke eksplicit interesserer sig for socialfaglig analyse er unders $\varnothing$ gelsen særdeles relevant i denne sammenhæng, da brug af viden indgår som et væsentligt element i socialfaglig analyse og perspektivet om beslutningsprocesser indfanger fænomener tæt på den socialfaglige analyse. De akademiske medarbejdere som er interviewet i unders $\varnothing$ gelsen, argumenterer for at evidensbølgen har ført til at ledere generelt forventer mere systematiske tilgange af medarbejderne uanset hvilken specifik metode, som de arbejder med (Møller 2018).

Stina Krogh Petersen har i sin ph.d. "At unders $\varnothing$ ge og blive unders $\varnothing g t "$ lavet feltarbejde i tre kommuners myndighedsafdelinger, hvor hun sætter fokus på den professionelle praksis relateret til den børnefaglige undersøgelse. Feltarbejdet er suppleret af seks fokusgruppeinterview med socialarbejdere og 14 personlige interviews med familier, dvs. både socialarbejdernes og familiernes perspektiv indgår i afhandlingen. I alle tre kommuner bruger socialarbejderne ICS (Integrated Children's System ${ }^{5}$ ) som fælles metode i den børnefaglige unders $\varnothing$ gelse, men opgaverne udfolder sig alligevel vidt forskelligt i kommunerne. I kommune

\footnotetext{
${ }^{5}$ ICS er en socialfaglig sagsbehandlings- og udredningsmetode, som anvendes i flertallet af danske kommuner (Kvalitet i sagsbehandlingen 2018).
} 
A indgår socialfaglige analyser uformaliseret og tilfældigt $\mathrm{i}$ arbejdet, og de finder primært sted horisontalt mellem kolleger. I kommune B er der en organisatorisk underst $\varnothing$ ttelse af faglige tilgange, og socialarbejderne bruger problemformuleringer som strukturerende for unders $\varnothing$ gelsesarbejdet i forhold til hvilken viden der skal indhentes og hvilke aktører der skal involveres. Der er en fælles refleksionspraksis, som underst $\varnothing t t e s$ af ledelsen. Socialarbejderne fra kommune B fremhæver i fokusgruppeinterview, at metoderne i den børnefaglige unders $\varnothing$ gelse er med til at give en sikkerhed i børn- og ungesager, hvor et vilkår i udførelsen af opgaverne er tvivl og usikkerhed. I kommune $\mathrm{C}$ arbejder socialarbejderne med en problemindkredsning uden en egentlig problemstilling. Dette gør unders $\varnothing$ gelsesarbejdet uforudsigeligt og ofte omfangsrigt (Petersen 2017). Feltarbejdet peger på en vigtig kvalificering af diskussionen om brug af fælles strukturer og lignende: Implementeringen af fælles standarder er en afgørende faktor for udfoldelse af systematikken. Sørensen henviser i samklang med dette til Munro, som også i en engelsk kontekst peger på at problemet ved brug af standarder ofte er, at socialarbejderne er skeptiske overfor standarder og benytter dem halvhjertet (Munro 2008 i Sørensen 2016b, Sørensen 2018). Nyathi når i tråd med dette i sin unders $\varnothing$ gelse frem til, at de engelske socialarbejdere bruger redskaber i sagsarbejdet i mindre grad end tiltænkt (Nyathi 2018). Sørensen peger supplerende på at det det typisk tager længere tid at indarbejde nye tilgange i socialt arbejde med børn og unge end tiltænkt i planlægningsfasen (Sørensen 2018).

\section{Opsummering}

Opsummerende om fælles struktur og standarder kan der peges på enighed mellem danske, norske og engelske forskere om at anbefale brug af en kombination af standardiserede redskaber og professionelt

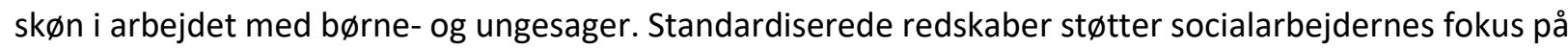
centrale grundelementer i børne- og ungesager, mens socialarbejderen via arbejdet med skøn kan udvise en følsomhed overfor og tilpasning til det unikke i sagerne. Undersøgelser fra Norge peger tilsammen på at systematik ikke alene kan opnås gennem fælles skabeloner men også gennem en skønsmæssig tilgang, som baserer sig på socialarbejdernes uddannelse og en professionsorientering. Ud fra en analyse af Serious Case Reviews (SCR) og en unders $\varnothing$ gelse af uf $\varnothing$ dte børn i Storbritannien argumenterer forskere for udvikling eller brug af fælles redskaber i sager om henholdsvis omsorgssvigt og ufødte børn. Analysen af SCR peger på at socialarbejderne undervurderer betydningen af omsorgssvigt i en stor del af sagerne. Omsorgssvigt kan være sværere at indfange i børne- og ungersager sammenlignet med mere åbenlyse sager om vold og misbrug. Fælles redskaber kan relatere socialarbejderes normalisering af forhold i socialt udsatte lokalområder, som bl.a. er påvist i en undersøgelse om fattigdom i England og Skotland, til en national standard, og på den måde kan fælles standarder være afsæt for et fokus på lokale forskelle.

Et helt afgørende opmærksomhedspunkt i forhold til brug af fælles systematik i form af metoder, redskaber mv. er, baseret på Stina Krogh Petersens feltarbejde i tre danske kommuner, om der sker en fælles implementering. Engelske forskere peger også på at socialarbejdere ofte kun delvist bruger fælles tilgange. Andre interessante fund i nyere danske undersøgelser viser at der i højere grad end tidligere er forventninger til socialarbejdere om at de kan arbejde systematisk og at socialarbejderne er positive overfor at arbejde ud fra retningslinjer og modeller. 


\subsubsection{Individuel eller kollektiv tilgang \\ En kollektiv tilgang}

Af vores undersøgelsesspørgsmål for forskningsoversigten fremgår det ikke om der er tale om individuelle eller kollektive processer i arbejdet med socialfaglig analyse. Denne diskussion trænger sig imidlertid på efter gennemgangen af materialet i forskningsoversigten.

Anne Mette Møller har i sin ph.d. iagttaget en systematik ved at sagsdiskussioner i de to kommuner struktureres i tre faser: 1) sagen fremlægges og socialarbejderen, som har den, forklarer hvad hun/han ønsker hjælp til 2) mødedeltagerne kan stille spørgsmål 3) fælles refleksioner over næste skridt. Ifølge forfatteren er der er flere formål med belysning af sager: At dele viden for at udøve kollektive professionelle skøn, at sikre emotionel støtte og åbne for en undersøgende tilgang til personviden, som kan bringe frustrationer frem i lyset og forstyrrelser i forhold til vurderingen. På denne måde kan ekspertinstitution adskilles fra ubearbejdede følelsesmæssige reaktioner og personlige idiosynkrasier, og personlige vurderinger omformes til en kollektiv opgave, hvor ansvar for beslutninger og resultater deles med teamet. (Møller 2018)

En hovedpointe hos Anne Mette Møller er, at beslutninger i høj grad udfolder sig som fortsatte, kollektive, samarbejdsorienterede og organisatorisk formede processer i de kommunale børne- og familieafdelinger. Denne type processer foregår på bagscenen, der supplerer forscenen hvor samarbejdet med børn, unge og familier foregår.

En forklaring på at sagsprocesser i stigende grad er gjort kollektive i danske kommuner kan være at det er en konsekvens af $\varnothing n s k e t$ om strammere $\varnothing$ konomistyring. Mange kommuner har som led i $\varnothing$ konomistyring oprettet visitationsudvalg, medstyrende teams med kollektiv kompetence og lignende mødefora, hvor der skal ske en godkendelse af analyser og vurderinger før en indsats kan bevilliges (Matthiessen, Zeeberg \& Haack 2017) og det har trukket sagsarbejdet i en mere kollektiv retning.

Helm \& Roesch-Marsh peger i forlængelse af dette på betydningen af beslutningsprocesser i grupper, både formelle og uformelle, i socialt arbejde med børn, unge og familier (Helm \& Roesch-Marsh 2016). De tager afsæt i erfaringsbaseret viden og opsamling på en række unders $\emptyset$ gelse, og de kritiserer en stor del af forskningen på feltet for at overbetone individuelle værdier, kompetencer og viden og underbetone kontekst, kultur og fælles værdier. Kettle \& Jackson laver en diskursanalyse af rapporter om socialt arbejde, og fremhæver at opmærksomheden retter sig mod socialarbejdernes praksis og psykologiske forhold fremfor de strukturelle forhold for praksis (Kettle \& Jackson 2017).

\section{En individuel tilgang}

Hvor Anne Mette Møller og Helm \& Roesch-Marsh når frem til at systematik i sagsarbejdet må ses som en del af kollektive processer, fremhæver Kresta Munkholt Sørensen, at socialarbejdere ofte udarbejder socialfaglige analyser på egen hånd. Dette forklarer hun med, at den formelle adgang til faglig refleksion blandt kolleger i mange tilfælde ikke er en mulighed pga. mangel på tid til teammøder og lignende møder. Den enkelte socialarbejder må derfor på eget initiativ søge uformel støtte, og dette sker kun i nogle af sagerne (Sørensen 2016). 
Stina Krogh Petersen finder frem til at socialarbejdernes refleksioner i forbindelse med den børnefaglige unders $\varnothing$ gelse i kommune A primært foregår hos socialarbejderne selv og sekundært med kolleger. Der er stor metodisk og teoretisk frihed, som ikke udelukkende opfattes positivt af socialarbejderne. Friheden kan også bidrage til tilfældighed, faglig ensomhed og stedvis frustration i udfoldelsen af undersøgelsesarbejdet. I kommune B bliver socialarbejderne 'holdt i hånden' og st $\varnothing$ ttet i opgaven med børnefaglige unders $\varnothing$ gelser gennem faglige tilgange, metodiske værktøjer, dialogmøder mv. I kommune C sker indsamlings- og refleksionspraksisser oftest hos den enkelte socialarbejder og ikke i et fælles, fagligt forum (Petersen 2017).

\section{Kritik af kollektive beslutningsprocesser i den aktuelle praksis}

Selv om Anne Mette Møller, Kresta Munkholt Sørensen og Stina Krogh Petersens fund og betoninger er forskellige, så er de enige om at de fælles møder i børne- og familieafdelinger og uformel sparring spiller en vigtig rolle i arbejdet med systematik. Kresta M. Sørensen og Anne Mette Møller er også enige om en kritik af hvordan de kollektive processer fungerer i praksis. Anne Mette Møller peger særligt på, at børne- og familieafdelingernes praksisfælleskaber er ustabile eller endda ikke eksisterende pga. den høje medarbejdermobilitet på feltet og derfor fungerer de langt fra altid som kollektive vidensreservoirs. De socialfaglige koordinatorer har en afgørende rolle i forhold til at opbygge organisatoriske rutiner og praksisfællesskaber, men de har svært ved at finde tid til opgaven pga. travlhed (Møller 2018).

Nyanthi har unders $\varnothing$ gt det sociale arbejde i et engelsk distrikt. Unders $\varnothing$ gelsen omfatter 22 personlige interviews med socialarbejdere, deltagende observation af møder og analyse af 20 SCR. På baggrund af unders $\varnothing$ gelsen er han kritisk overfor gruppem $\varnothing$ der, fordi både ledere og socialarbejdere søger konsensus, og der mangler åbenhed overfor alternative ideer og standpunkter og viden udefra (Nyanthi 2018). Stina Krogh Petersen fremhæver i denne sammenhæng socialfaglig ledelse som et fænomen, der har en langt større betydning end hun var opmærksom på ved afhandlingens begyndelse (Petersen 2017).

\section{Opsummering}

Opsummerende om en individuel eller en kollektiv tilgang er der et vigtigt spørgsmål om arbejdet med socialfaglig analyse, som ikke er gjort eksplicit i vores forskningsspørgsmål og i notatet om socialfaglig analyse: er der tale om individuelle eller kollektive processer i arbejdet med socialfaglig analyse? En hovedpointe hos Anne Mette Møller er, at beslutninger i høj grad udfolder sig som fortsatte, kollektive, samarbejdsorienterede og organisatorisk formede processer i de kommunale børne- og familieafdelinger. Hun tillægger ud $\varnothing$ velsen af kollektivt professionelt sk $\emptyset n$ afg $\varnothing$ rende betydning for kvaliteten af arbejdet $\mathrm{i}$ børne- og ungesager bl.a. ved at der mobiliseres emotionel st $\varnothing t t e$, åbnes for at bringe frustrationer frem i lyset og filtrere personbundne forstyrrelser fra i forhold til børnefaglige vurdering. Samtidig fremhæver hun, at børne- og familieafdelingernes praksisfælleskaber er ustabile eller endda fraværende på dele af feltet, og det kan være grundlag for at Stina Krogh Petersen og Kresta Munkholt Sørensen peger på, at socialarbejderne i mange tilfælde selv uformelt skal opsøge sparring og at der også er en del alene arbejde og tilfældigheder i børnefaglige sager. Anne Mette Møller har unders $\varnothing g t$ to af landets store kommuner og i de tre kommuner Stina Krogh Petersen har unders $\varnothing \mathrm{gt}$, er arbejdsprocesserne gjort mest kollektive i den største af kommunerne, mens der er flere individuelle arbejdsprocesser i to mindre kommuner.

\subsubsection{Hvordan kobler faserne beskrivelse, analyse og vurdering sig til den socialfaglige analyse?} Opdelingen af sagsarbejdet i de tre elementer, beskrivelse, analyse og vurdering, kan ses som en specifik del af systematik i sagsarbejdet. Opdelingen er central på efter- og videreuddannelse for fagprofessionelle i Danmark, hvor den fremhæves som vigtig i ni ud af 14 lærebogs- og håndbogstekster (Schnohr, Andersen \& 
Matthiessen 2020; 6-7). Opdelingen indgår derfor i operationaliseringen af socialfaglig analyse her. Gennemgangen af materialet i forskningsoversigten viser imidlertid, at forskerne i langt mindre grad er optaget af denne opdeling. I to undersøgelser nævnes beskrivelse, analyse og vurdering (Sørensen 2016b; Turney \& Ruch 2018), men opdelingen ikke indgår i de øvrige 24 artikler og forskningsprojekter.

Forskellen kan skyldes, at opdelingen beskrivelse, analyse og vurdering er så indarbejdet, at der er tale om tavs viden på feltet. En anden forklaring kan være at opdelingen i højere grad er et ideal for fagprofessionelle, som indgår i lærebøger, end en praksis, som viser sig i empiriske unders $\varnothing$ gelser. En del af forskerne er optaget af beslutningsteori som en anden måde at begrebsliggøre processer i børne- og ungesager på (Heggdalsvik, Rød \& Heggen 2018; Helm \& Roesch-Marsh 2016; Møller 2018; Nyanthi 2018; Skotte 2016).

Stina Krogh Petersen peger overordnet på, at indsamling af viden i børne- og ungesager er mere reguleret i Serviceloven end refleksionsarbejdet, som fastlægges i den enkelte kommune (Petersen 2017). Hun opdeler inspireret af praksisteori arbejdet med den børnefaglige unders $\varnothing$ gelse i indsamlingspraksisser og refleksionspraksisser fremfor beskrivelse, analyse og vurdering. I kommune A og B går indsamlingspraksisserne forud for refleksionspraksisser og følger derfor umiddelbart opdelingen af arbejdet med den børnefaglige unders $\varnothing$ gelse i faserne beskrivelse og analyse, mens de to praksisser løbende veksler i kommune C (Petersen 2017).

I et mindre aktionsforskningsprojekt fra to kommunale enheder i England baseret på individuelle og gruppesupervisioner er en iagttagelse, at nogle socialarbejdere er forbeholdne overfor en grundig beskrivelse i sagerne. De vil hellere hurtigt videre til problemløsning. En socialarbejder forklarer, at der er risiko for, at man ser ting, som man hellere vil undgå at se, når man laver grundige beskrivelser, og at der kan være store følelsesmæssige omkostninger ved at se hvad der faktisk er foran én.

Aktionsforskningsprojektet peger mere generelt på, at den aktuelle praksis i børne- og familiearbejdet privilegerer 'at gøre' på bekostning af 'at tænke 'eller 'at føle' (Turney \& Ruch 2018).

\section{Opsummering}

Opsummerende om opdelingen af sagsarbejdet i de tre elementer, beskrivelse, analyse og vurdering gælder at opdelingen kan ses som en specifik del af systematik i sagsarbejdet. Opdelingen er central i videreuddannelse for socialarbejdere i Danmark, men gennemgangen af materialet viser, at forskerne i forskningsoversigtens artikler stort set ikke er optaget af denne opdeling. En forklaring kan være at opdelingen i højere grad er et ideal for socialarbejdere, som indgår i lærebøger, end en praksis, som kommer til udtryk i empiriske undersøgelser.

\subsubsection{Hvordan er sammenhængen mellem den socialfaglige analyse og

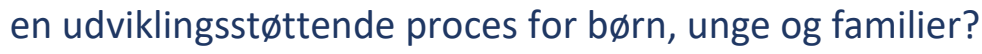

\section{Inddragelse har en tilfældig karakter}

To af de danske unders $\varnothing$ gelser interesserer sig for sammenhængen mellem den socialfaglige analyse og

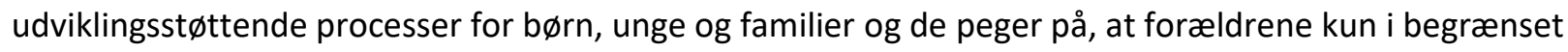
omfang oplever at sagsforløb bidrager til st øtte til egen udvikling og empowerment (Kildedal, Uggerhøj, Nordstoga \& Sagatun 2010, Petersen 2018).

Ifølge Kildedal, Uggerhøj, Nordstoga \& Sagatun ligger der i dansk lovgivning klare krav om, at den børnefaglige unders $\varnothing$ gelse skal gennemføres, så den bliver en erkendelses- og læreproces for familien. 
Forskerne har interviewet 10 familier fra to norske kommuner og syv familier fra en dansk kommune om deres erfaringer fra børnefaglige unders $\varnothing$ gelsesforl $\emptyset b$ (Kildedal m.fl. 2010). Unders $\varnothing$ gelsen er baseret på et kritisk udvalg af familier, som har haft et godt undersøgelsesforløb og samarbejde med kommunen med det formål at finde frem til positive erfaringer om udviklingsst $\varnothing t t e n d e$ forløb. Et overraskende resultat er derfor, at familierne ikke i særlig høj grad havde erfaringer med, at den børnefaglige unders $\varnothing$ gelse bidrog til at støtte dem i at håndtere deres liv. Mange familier var utrygge og følte sig objektgjorte undervejs $i$ forløbet. De oplevede at det alene var myndigheden, som havde ejerskabet til den børnefaglige unders $\varnothing$ gelse og at inddragelsen af familieperspektivet havde en tilfældig karakter. Flere forældre tilføjede, at det påvirkede deres opfattelse af den børnefaglige undersøgelse, at socialarbejderen omtalte den børnefaglige unders $\varnothing$ gelse negativt. Et opmærksomhedspunkt i forhold til unders $\varnothing$ gelsen er at data er indsamlet i 2010 eller $f ø r$, og forholdene kan have ændret sig siden.

\section{Hierakisk versus kontekstuelt videnssyn}

En konklusion i Stina Krogh Petersens komparative undersøgelse af tre danske kommuner er at kriterierne for og synet på viden har afgørende indflydelse på den professionelle praksis. Hun opererer med et hierakisk videnssyn overfor et kontekstuelt videnssyn. I kommune A observerer hun en hierarkisering af viden, hvor professionelles viden ses som mere troværdig end familiernes viden. Her er lære- og erkendelsesprocesser defineret ved, at familierne skal flytte sig i retning af de fagprofessionelles forståelse af problemerne. Dvs. praksis i kommunen er tæt på et hierakisk videnssyn. I kommune B bliver problemformuleringen for den børnefaglige unders $\varnothing$ gelse udarbejdet kollektivt i det faglige team, men familierne oplever at de er med til at fastsætte undersøgelsens fokus. I denne kommune deler og forhandler socialarbejderne viden med familien. Her arbejder socialarbejderne tættere på et kontekstuelt videnssyn. I kommune $\mathrm{C}$ indsamler socialarbejderen viden fra familien, men vender $\mathrm{i}$ begrænset omfang tilbage med status på undersøgelsen, invitation til fælles refleksion mv.. (Petersen 2017)

\section{Samarbejdet med forældre og unge}

Unders $\varnothing$ gelsen om det ufødte barn af Lusley et al. viser, at de fleste forældre tager imod myndighedernes opfordring til at deltage i en før-fødselsunders $\varnothing$ gelse, men at de professionelle vurderer, at der er utilstrækkelig støtte til forældrene under graviditeten (Lushey et al. 2017). Dvs. der lader til at være et potentiale for at arbejde udviklingsst $\varnothing$ ttende med forældrene, som aktuelt ikke udnyttes.

Holt \& Kelly laver en syntese af en række empiriske undersøgelser i en metaanalyse af hvordan rammerne for samarbejde mellem myndigheder og forældre har udviklet sig i England. De peger på at nedskæringer i det sociale system og en række detaljerede ændringer i lovgrundlag og retssystem gør det vanskeligt for socialarbejdere at indgå i partnerskaber med forældre og arbejde ressourceorienteret med tilbud om st $\varnothing t t e$. En del af udviklingen er specifik engelsk, men forfatterne argumenterer for at der er generaliserbare aspekter af analysen, da også andre landes sociale systemer i stigende grad reguleres af kompleks lovgivning og detaljerede procedurer (Holt \& Kelly 2013).

Kettle \& Jackson anbefaler ud fra en SCR-gennemgang, at socialarbejdere bør være opmærksomme på at danne relationer til familier med en passende distance. Hvis relationen er for tæt, risikerer socialarbejderen at miste sit professionelle perspektiv og overse informationer i sagen, og hvis relationen er for distanceret, kan socialarbejderen få vanskeligt ved at skabe en arbejdsalliance med familien (Kettle \& Jackson 2017). 
Solem, Diaz \& Hill argumenterer ud fra deres SCR-analyse for at socialarbejderne med fordel kan bruge et fælles unders $\varnothing$ gelses- og monitoreringsredskab i dialogen om med forældrene af, hvordan omsorgssvigt påvirker barnet (Solem, Diaz \& Hill 2019).

Et californisk studie er baseret på en analyse af 39 sager om børn og unge fra 12-års alderen og opefter. Analysen handler om at finde eksempler på god praksis. Sagsgennemgangen tyder ifølge forfatterne på, at de unge i sagerne ofte er i stand til at opnå positive ændringer, når de får indflydelse på hvordan de kan nå deres mål. Konkrete eksempler på god praksis er en socialarbejder, der med regelmæssige mellemrum beder de unge beskrive deres behov og komme med forslag til hvordan problemer kan løses, da denne beskrivelse hjælper de unge til en $\varnothing$ get indsigt i egen situation og giver grundlag for forhandling om og imødekommelse af de unges egne løsningsforslag (Carnochan, Weissinger, Henry, Liner-Jigamian \& Austin 2018).

\section{Opsummering}

Opsummerende om sammenhængen mellem socialfaglig analyse og udviklingsst $\varnothing$ ttende processer for børn, unge og familier gælder det at to af de danske undersøgelser interesserer sig for denne sammenhæng. Begge unders $\varnothing g e l s e r$ viser, at forældrene kun i begrænset omfang oplever at samarbejde med socialarbejderne i sagsforl $\varnothing b$ bidrager til st $\varnothing$ tte til egen udvikling. I den mest kritiske unders $\varnothing$ gelse er der udvalgt en gruppe forældre, som havde en positiv holdning til samarbejdet med kommunen, hvilket styrker holdbarheden af dette fund.

\subsubsection{Indgår analysen som en afgrænset del af sagsforløbet eller som en kontinuerlig og foranderlig proces? \\ Socialfaglige analyser som processuelle}

I både danske, svenske og engelske undersøgelser som interesserer sig for det tidsmæssige omfang af socialfaglige analyser eller beslutningers karakter, er der enighed om, at analyse og beslutninger mere udfolder sig som processer igennem sagsforløbet fremfor i særligt afgrænsede dele af sagsforløbet.

Anne Mette Møller ser i sin ph.d. beslutninger udfolde sig som kontinuerlige og processuelle fremfor afgrænsede og definitive i en rodet virkelighed med mange usikkerheder i børn- og ungearbejdet. Feltarbejdet tyder på, at de fagprofessionelle og deres ledere mere ser beslutningsprocesser som indgange til familiernes liv end som løsninger. Beslutninger er lige så meget begyndelser som de er afslutninger. Ofte bruger ledere, koordinatorer og socialarbejdere udtrykket 'at skabe retning' fremfor 'at tage beslutninger' (Møller 2018; 174, egen oversættelse), hvilket er en sproglig indikator på, at der er tale om en proces med åbenhed.

I Stina Krogh Petersens komparative studie beskrives undersøgelsespraksisserne i kommune B som gensidige og responsive processer, og i kommune $C$ som en eksplorativ vekslen mellem indsamlings- og refleksionspraksis, som imidlertid set fra et familieperspektiv fører til uigennemsigtighed. Det fremgår ikke klart hvordan socialrådgiverne i kommune $\mathrm{A}$ arbejder (Petersen 2017).

\section{Vendepunkter i sager}

Kettle har unders $\varnothing$ gt beslutninger med store konsekvenser i sociale sager i Skotland i sin ph.d., som bl.a. omfatter 22 interviews med socialarbejdere og analyse af 20 SCR. Han skriver, at det ikke så meget er én beslutning, der fører til et vendepunkt i en sag, men snarere en kompleks proces bestående af mange interne og eksterne udløsende faktorer bl.a. sagsbehandlerskift, reorganiseringer af sagsakter, ændringer $\mathrm{i}$ familiens livsvilkår, socialarbejderens refleksioner og interaktioner med andre professionelle (Kettle 2017). 
Enell \& Denvall er optaget af beslutninger om og vurderinger af indsatser for unge på sikrede institutioner i Sverige. De påpeger på baggrund af en spørgeskemaundersøgelse og interviews med 16 socialarbejdere og unge som gentages efter et halvt år, at både vurdering og valg af indsats kan ses som en del af en proces, der i nogle tilfælde kan stå alene, men i andre tilfælde fungerer som en begyndelse på en anden indsats (Enell \& Denvall 2017).

\section{Opsummering}

Opsummerende for de syv studier som i en eller anden grad interesserer sig for om det tidsmæssige omfang af analysen eller beslutningers karakter er der udstrakt enighed om, at der er tale om en proces fremfor en afgrænset del af sagsforløbet. Dette gælder både danske, svenske og engelske undersøgelser (Møller 2018; Petersen 2017; Enell \& Denvall 2017; Lusley, Barlow, Rayns \& Ward 2017; Morris et al. 2018; Solem, Diaz \& Hill 2019; Kettle 2017).

\subsection{Vidensformer}

\subsubsection{Samspil mellem vidensformer i socialt arbejde}

\section{De mest udbredte vidensformer}

En pointe hos Anne Mette Møller er, at tavs viden ikke længere er tilstrækkeligt i den professionelle praksis. Der er forventninger om en mere eksplicit form for professionalisme, hvor socialarbejdere forstår teorier og redskaber i en grad, så de kan anvende dem analytisk og forklare deres tænkning overfor borgerne (Møller 2018).

De mest omtalte vidensformer i socialarbejdernes praksis i forskningsoversigtens materiale er lovgivningsmæssig viden i de engelske unders $\varnothing$ gelser (Firmin 2018; Forrester 2017; Helm \& Roesch-Marsh 2016; Kettle \& Jackson 2017; Lucas 2019; Lushey et al. 2017) og intuitiv viden (bl.a. Kettle 2017; Kettle \& Jackson 2017; Lushley et al. 2017; Nyathi 2018; Petersen 2017).

\section{Anne Mette Møllers seks vidensformer}

Nyathi og Roesch-Marsh arbejder med velkendt opdeling mellem intuitiv og analytisk viden, som de fremhæver som komplementære og i samspil (Nyathi 2018; Roesch-Marsh 2016). Til forskel fra dette er Anne Mette Møller fortaler for at arbejde på tværs af de to vidensformer og skelne mellem; Propositionel viden (knowing that) bl.a. faktuel viden om national og lokal politik, lovgivning, lokale politikker og standarder, forskningsbaseret viden, teori, redskaber, retningslinjer; Proceduremæssig (knowing how); tillærte færdigheder, vaner og holdningsmønstre og; Viden om konkrete personer (personal knowledge). Hver af de tre vidensformer har, argumenterer hun for, både intuitive eller tavse og eksplicitte elementer, dvs. Anne Mette Møller udvider de to vidensformer til seks: tavs og eksplicit proportionel viden, tavs og eksplicit proceduremæssig viden og tavs og eksplicit viden om personer. De tavse komponenter er ifølge Anne Mette Møller i en eller anden grad personlige. Proceduremæssig viden mobiliseres gennem induktiv, sagsbaseret læring på arbejdspladsen (Møller 2018).

Som en yderligere nuancering peger Turney \& Ruch på betydningen af følelsesmæssig information i sagsarbejdet (Turney \& Ruch 2018). De to forskere anbefaler, at hændelsesinformation i sagsforløb udvides med følelsesmæssig information, som giver vigtig komplementær viden. Denne anbefaling kobler sig til den sagsspecifikke viden eller det Anne Mette Møller betegner viden om personer.

\section{Brug af forskningsbaseret viden i praksis}

Evidensbølgen i socialt arbejde har skabt særlig opmærksomhed om brugen af forskningsbaseret viden i praksis. Anne Mette Møller henviser til et review fra SCIE (Social Care Institute for Excellence) i 
Storbritannien, som viser at socialarbejdere bruger forskningsbaseret viden i deres praksis, men at $\varnothing$ vrige vidensformer er mere fremtrædende bl.a. borgerevalueringer, lovgivning, faglige normer og erfaringsbaseret viden. En række forskere argumenterer ifølge Anne Mette Møller for at forskning påvirker praksisfeltet mere indirekte end direkte. Det sker gennem komplekse, iterative og socialt situerede processer. Forskningsviden udgør ofte en baggrund af ideer, empiriske unders $\varnothing g e l s e r$ og data, som informerer den måde socialarbejdere forstår problemer på. (Møller 2018)

\section{Opsummering}

Opsummerende om samspillet mellem vidensformer i socialt arbejde skelner Anne Mette Møller mellem tre forskellige vidensformer i det sociale arbejde; Propositionel viden (knowing that); Proceduremæssig (knowing how) og; Viden om personer. Hver af de tre vidensformer har både intuitive eller tavse og eksplicitte elementer. Til forskel fra dette bruger engelske forskere en mere enkel men også mindre præcis og nuanceret opdeling i intuitiv og analytisk viden. Proceduremæssig viden mobiliseres gennem induktiv, sagsbaseret læring på arbejdspladsen.

\subsubsection{Hvordan mobiliseres vidensformer i praksis? \\ Organisatorisk mobilering af viden}

Som nævnt under punktet systematik er et væsentlig svar på hvordan vidensformerne bruges i praksis hos Anne Mette Møller, at socialarbejderne arbejder med fælles vidensgrundlag. Hun peger på, at de professionelles autoritet på grundlag af specialiseret viden om socialt arbejde ikke længere er koblet til den enkelte professionelle, men er integreret i det organisatoriske mindset (Møller 2018). Forskydningen indebærer, at opgaven med at følge med i ny viden i høj grad er skubbet fra den enkelte fagprofessionelle til organisationen, hvor man arbejder med organisatorisk sanktioneret viden koblet op på tilgange, metoder og redskaber. Dvs. ansvaret for at være opdateret er gået fra socialarbejderne til deres organisationer. Fundet skal ses i lyset af at feltarbejdet er sket i to store kommuner, som er strategisk udvalgt pga. en interesse for at arbejde evidens- og vidensbaseret. Praksis kan være anderledes i $\varnothing$ vrige kommuner, men fundet er interessant da Herning og København tidligere har indtaget rollen som spydspidser i socialt arbejde bl.a. med indførelse af Sverigesmodellen (omd øbt til henholdsvis Herningmodellen og Tæt på familien) og derfor kan have en lignende rolle i forhold til mobilisering af vidensgrundlag. Stina Krogh Petersen finder i sin kortlægning af praksis i tre danske kommuner, at socialarbejderne bruger et fælles vidensgrundlag underst $\varnothing$ ttet af organiseringen i kommune $B$, mens socialarbejderne overvejende arbejder individuelt $\mathrm{i}$ kommune $A$ og $C$ (Petersen 2017). Kommune B er den st $\varnothing$ rste af de tre kommuner.

Det organisatoriske mindset repræsenterer if $\varnothing$ lge Anne Mette Møller 'a pecular mix of [.....] knowledge and taking a leap of faith', dvs. en mærkelig blanding af viden og tro, som ledere opfordrer socialarbejdere til at vælge at gå ind i og handle efter (Møller 2018; 160). Et fælles organisatorisk teoretisk og metodisk mindset kan medvirke til at skabe gennemsigtighed i relation til vidensgrundlaget for beslutningstagning og til at mediere forskningsbaseret viden på måder, så det bliver retningsgivende for praksis, men det indebærer samtidig en risiko for at professionelle standarder kan blive viklet ind i organisatoriske og politiske prioriteringer. Det er sjældent at viden, der ikke indgår i det organisatoriske mindset, mobiliseres. Tidsmangel betyder, at forskningsmæssig viden ofte mobiliseres tilfældigt snarere end systematisk. Mobiliseringen afhænger af enkelte medarbejderes muligheder og initiativer i forhold til at holde sig opdateret og desuden af om de pågældende medarbejdere deltager i sagsdrøftelserne. De faglige koordinatorer har ofte en rolle som vidensmobilisatorer, der indebærer, at de skal holde sig opdaterede på forskning og andre relevante videnskilder (Møller 2018). 


\section{Eksplicit versus tavs viden}

En norsk unders $\varnothing$ gelse med fokusgruppeinterview i seks socialarbejderteams underst $\varnothing$ tter pointen om, at en fælles tilgang kan bidrage til at forme forskningsviden som brugbar for praksis. I de to teams hvor man arbejdede med en skabelon inspireret af den norske psykolog $\varnothing$ yvind Kvello blev der refereret til denne forskningsviden, mens de teams der udelukkende brugte en skønsmæssig tilgang, ikke trak på eksplicit forskningsviden (Heggdalsvik, Rød \& Heggen 2018). Her bliver skelnen mellem tavs eller intuitiv viden og eksplicit viden imidlertid vigtig, da vi ikke ved om de norske socialarbejdere baserer sig på tavs viden fra forskning. Et andet norsk studie af 13 sager fra to kommuner viser, hvordan socialarbejderne implicit trækker på fælles teoretiske referencer fx fra udviklings- og tilknytningsteori, uden at begreber og referencer nævnes i sagsakterne. De 13 sager er unders $\varnothing$ gt via feltobservationer og interviews på arbejdspladsen og sagernes skriftlige materiale. Dvs. med Anne Mette Møllers terminologi er der tale om propositionel, tavs viden. Derudover viser Skottes unders $\varnothing$ gelse, at socialarbejdere trækker på erfaringsbaseret viden fra tidligere sager (Skotte 2020), hvilket underst $\varnothing t t e s$ af fund hos Anne Mette Møller, som peger på, at det genererer ny viden, når fagprofessionelle bruger viden i praksis (Møller 2018).

Når man laver en professionel vurdering, vurderer man ifølge Anne Mette Møller relevansen af abstrakt viden i en sag. Hun argumenterer for, at professionel dømmekraft er, hvordan professionelle forstår et problem og giver det mening. Denne proces omfatter at skabe mening i mange konfliktende og forvirrende data og at nå frem til en problemdefinition (Møller 2018).

\section{Opsummering}

Opsummerende om mobilisering af viden er en pointe hos Anne Mette Møller, at tavs viden ikke længere er tilstrækkeligt i den professionelle praksis. Der er forventninger om en mere eksplicit form for professionalisme. Hun fremhæver, at der er sket en forskydning fra den enkelte professionelle til organisationen i mobilisering af viden. Forskydningen indebærer, at opgaven med at følge med i ny viden i høj grad er skubbet fra den enkelte fagprofessionelle til organisationen, hvor man arbejder med organisatorisk sanktioneret viden koblet op på tilgange, metoder og redskaber. Mao. har ansvaret for at være opdateret i forhold til ny viden flyttet fra socialarbejderne til deres organisationer. Igen skal dette fund ses i lyset af at de to kommuner som indgår i Anne Mette Møllers feltarbejde er store kommuner som indtager en rolle som spydspidser i det kommunale felt i forhold til at arbejde evidens- og vidensbaseret.

Et fælles organisatorisk teoretisk og metodisk mindset kan medvirke til at skabe gennemsigtighed $\mathrm{i}$ vidensgrundlaget for beslutningstagning, så det bliver retningsgivende for praksis, men det indebærer samtidig en risiko for at professionelle standarder kan blive viklet ind i organisatoriske og politiske prioriteringer. Fra et familieperspektiv peger Stina Krogh Petersens unders $\emptyset$ gelse på gennemsigtighed som en afgørende faktor for et godt samarbejde med kommunen om den børnefaglige unders $\varnothing$ gelse.

Udfordringer ved en fælles organisatorisk tilgang er ifølge Anne Mette Møller at viden, der ikke indgår i det organisatoriske mindset, sjældent mobiliseres. Derudover afhænger vidensomsætningen i organisationen af vidensmobilisatorers muligheder og initiativer i forhold til at holde sig opdaterede, hvilket sker $\mathrm{i}$ konkurrence med andre arbejdsopgaver.

\subsection{Perspektiver}

\subsubsection{På hvilken måde indgår borgernes perspektiv som en del af analysen?}

\section{Mødrenes og fædrenes perspektiv}

Spørgsmålet om borgernes perspektiv opdeler vi nedenfor i først familiens og netværkets perspektiv og derefter børn og unges perspektiv. 
I Kildedal m.fl.s interviewunders $\emptyset$ gelse med 17 danske og norske familier giver familierne udtryk for en oplevelse af, at den børnefaglige undersøgelse foregår 'uden for' familien, og det alene er socialforvaltningen som har ejerskabet (Kildedal m.fl. 2010; 6). Desuden er et fund i unders $\varnothing$ gelsen, at det oftest er moderen som er den primære samarbejdspartner for socialforvaltningen, og fædrene ser ud til at være perifere både $f \varnothing r$, under og efter unders $\varnothing$ gelsesarbejdet. Forfatterne konkluderer, at inddragelse af familierne har en tilfældig karakter, men også at der er stor forskel på i hvilken grad socialarbejderne informerer familierne og at familierne oplever forløbene forskelligt afhængig af hvilken socialarbejder de samarbejder med (Kildedal m.fl. 2010). Kresta Munkholt Sørensen finder til forskel fra dette nogle år senere frem til, at fædrene i langt højere grad er involveret sammenlignet med tidligere forskningsfund. Men hvor familierne selv er spurgt i Kildedal m.fl.'s unders $\varnothing$ gelse, er unders $\varnothing$ gelsesgrundlaget i Kreta Munkholt Sørensens materiale en survey og interviews med ledere og socialarbejdere, og ikke med familierne (Sørensen 2016a).

\section{Forældre som informanter}

Stina Krogh Petersens afhandling viser, at forældrene er informanter men i mindre udstrækning dialog- og samarbejdspartnere under den børnefaglige unders $\varnothing$ gelser. I kommune A er det kun via samtaler og møder at familierne har en mulighed for at gøre deres perspektiv gældende. I kommune B er indsamlingspraksisser lavet til et 'gennemsigtigt maskinrum' (Petersen 2017; 203), hvor særlig dialogmøderne sætter familierne i stand til at overvære, deltage i og måske endda udfordre andre aktørers viden om familien. I kommune $C$ inddrages familierne alene via de lovpligtige samtaler ved opstarten af den børnefaglige unders $\varnothing$ gelse. Familierne deltager ikke nævneværdigt i socialrådgivernes refleksionsprocesser. Der er alene en åbenhed overfor dette i kommune B, ikke i kommune $\mathrm{A}$ og $\mathrm{C}$. Pointer $\mathrm{i}$ afhandlingen er desuden at forældrene foretrækker en afgrænset, eksplicit unders $\varnothing$ gelsespraksis med transparens fremfor uformelle, åbne og eksplorative processer. Overraskende i forhold til udbredte professionsforestillinger og anden forskning (se fx Kongsgaard 2014, kapitel 2) finder Stina Krogh Petersen, at det som socialarbejderne ser som relationsarbejde kan virke slørende for familierne i den børnefaglige unders $\varnothing$ gelse (Petersen 2017).

\section{Forældrenes vurdering af socialarbejdernes arbejde}

I en opsamling af en række unders $\varnothing$ gelser fra et engelsk forskningsprogram peger Forrester på, at et betydeligt mindretal blandt forældrene ikke mener, at de har behov for socialforvaltningens st $\varnothing$ tte. Når forældrene skal forklare ændringer i deres situation er det sjældent at de nævner socialarbejderen, ofte fortæller de, at problemerne er løst på andre måder. I sager hvor familien og socialarbejderen har set hinanden mindst otte gange er dette dog anderledes, her tillægger familierne socialarbejderen en betydning i håndteringen af deres problemer. Derudover er et problem som identificeres i materialet at socialarbejdere og kontormedarbejdere på socialforvaltningen 'taler ned' til forældrene (Forrester 2017: 150, egen oversættelse).

Lucas har i sin ph.d. interviewet 20 forældre og bedstem $\varnothing$ dre om deres oplevelse af at indgå i samarbejdet med fagprofessionelle om en tidlig indsats i et engelsk distrikt. Den tidlige indsats bliver til i tværprofessionelle miljøer, som forældrene oplever som komplekse og hvor deltagelse forudsætter 'institutional literacy' (Lucas 2019; 534), dvs. kompetencer til at afkode og navigere i den specifikke institutionelle sammenhæng. I nogle sager har forældrene tillid til at en fagprofessionel varetager deres interesser i systemet, men i andre tilfælde oplever forældrene samarbejdet som en stresset proces, hvor de har haft svært ved at finde fodfæste (Lucas 2019).

Nyathi fremhæver i sin undersøgelse som bl.a. baserer sig på socialarbejderinterviews, observationer og sagsanalyse, at familiemedlemmer ofte ikke forstår baggrunden for beslutninger i børn- og ungesager og at en tilsyneladende konsensus mellem socialarbejder og familie kan være overfladisk (Nyathi 2018). 


\section{Opsummering}

Opsummerende i forhold til et borgerperspektiv oplever familierne ifølge flere danske undersøgelser, at det er kommunen som har ejerskabet til børnesagsforløbene. Inddragelse af familierne har en noget tilfældig karakter, og der er er stor forskel på hvordan familierne oplever forløbene afhængig af hvilken socialarbejder de samarbejder med. Et klassisk dilemma relateret til spørgsmål om ejerskab som indfanges i en engelsk undersøgelse er, at et betydeligt mindretal blandt forældrene ikke mener at de har behov for den støtte, som socialforvaltningen vurderer er påkrævet.

Stina Krogh Petersens afhandling viser, at forældrene er informanter men i mindre udstrækning dialog- og samarbejdspartnere under den børnefaglige undersøgelse. Familierne deltager ikke nævneværdigt i socialrådgivernes refleksionsprocesser. Inddragelsen af et forældreperspektiv lykkes bedst i den kommune som har den mest kollektiv tilgang til det sociale arbejde, og i begrænset omfang i de kommuner som har en mere individuel tilgang.

Lucas bruger begrebet 'institutional literacy' til at beskrive forældrenes kompetencer til at afkode og navigere i den specifikke institutionelle sammenhæng og peger på at forskelle i institutionelle læsekompetencer har betydning for forældrenes oplevelse af samarbejdet, og i forlængelse af dette er et fund $i$ en anden engelsk unders $\varnothing$ gelse at en tilsyneladende enighed mellem socialarbejder og familie om beslutninger kan være overfladisk.

\subsubsection{Inddragelse af børn og unge}

\section{Det usynlige barn i forskningen}

I flertallet af undersøgelser skelnes der ikke imellem et familieperspektiv og et børn- og ungeperspektiv. Det er desuden bemærkelsesværdigt at børne- og ungeperspektivet fremtræder indirekte gennem interview med andre aktører og sagsanalyse fremfor direkte i form af udsagn fra børn og unge. Det vil sige, at der i det samlede materiale er fravær af det Hanne Warming kalder et egentligt indefra perspektiv (Warming 2011).

Fænomenet 'det usynlige barn' bruges om sager i socialt arbejde, hvor det ikke lykkes socialarbejderen at relatere til barnet i tilstrækkelig grad (Solem, Diaz \& Hill 2019; 4, egen oversættelse). 'Det usynlige barn' lader til også at gøre sig gældende indenfor forskningen. Solem, Diaz \& Hill konkluderer i deres analyse af 20 SCR om omsorgssvigt, at barnets stemme ikke var hørt i en tilstrækkelig grad i 15 af sagerne. Forklaringer på at barnets perspektiv overses, kan ifølge forfatterne være forældres mangel på samarbejdsvilje, sagens kompleksitet og det kaos, der ofte er til stede i familier med komplekse problemstillinger (Solem, Diaz \& Hill 2019).

Større inddragelse af børn i en dansk sammenhæng?

Kresta Munkholt Sørensen når i sin afhandling om børnefaglige undersøgelser i en dansk kontekst frem til at 'børn generelt set $i$ langt højere bliver involveret $i$ den børnefaglige undersøgelse sammenlignet med tidligere forskningsfund' (Sørensen 2016: 63). Et opmærksomhedspunkt i denne sammenhæng er, at forfatteren har unders $\emptyset$ gt socialarbejdere og lederes opfattelse af dette, men børnene er ikke spurgt.

I Heggdalsvik, Rød \& Heggens unders $\varnothing$ gelse er et fund, at socialarbejdere fra teams, der arbejdede med Kvello-inspirerede skabeloner, talte mere direkte om børnenes perspektiv end de $\varnothing$ vrige teams, hvor børnene indgik mere indirekte i hypoteser, spørgsmål og muligheder, der blev diskuteret i fokusgrupperne. Der er ingen forklaring i artiklen på forskellen (Heggdalsvik, Rød \& Heggen 2018).

Kettle \& Jackson fremhæver en rapport, som anbefaler at socialarbejderne tillægger egne observationer af børn, unge og familie vægt fremfor alene at arbejde med forælderens forklaringer (Kettle \& Jackson 2017). 


\section{Opsummering}

Opsummerende skelnes der i flertallet af unders $\varnothing$ gelser ikke imellem et familieperspektiv og et børn- og ungeperspektiv. Børne- og ungeperspektivet fremtræder kun indirekte gennem interview med andre aktører og sagsanalyse fremfor direkte i form af udsagn fra børn og unge. Fænomenet 'det usynlige barn' som er kendt i socialt arbejde lader til således også at slå igennem i forskningen.

\subsubsection{Hvilke faglige perspektiver anvender socialarbejderen i analysen og hvordan bruges de? Risiko- og beskyttelsesfaktorer}

Kresta Munkholt Sørensen unders $\varnothing g e r$ brugen af de socialfaglige metoder bl.a. ICS (Integrated Children's System) og SOS (Signs of Safety) og her fremhæver hun især socialarbejdernes brug af risiko- og ressourcefaktorer som faglige perspektiver (Sørensen 2016). Samme faglige perspektiver træder frem i Stina Krogh Petersens unders $\varnothing$ gelse af tre ICS kommuner, særligt i kommune B (Petersen 2017).

I Skivenes \& Stenbergs vignetunders $\varnothing$ gelse af risikovurdering blandt norske, engelske og amerikanske socialarbejdere argumenterer de for, at socialarbejdernes tilgang til risikofaktorer må ses lyset af det aktuelle velfærdssystem. Således beskriver de i deres undersøgelse, at de norske socialarbejdere har en højere risikovurdering end socialarbejdere fra USA og England, og de argumenterer for, at tærsklen for at hjælpe familien er lavere i Norge end de to $\varnothing$ vrige lande. I Norge vil socialarbejdere oftere fors $\varnothing$ ge sig med indsatser overfor familien i hjemmet, mens der i de angelsaksiske lande med deres mere liberale socialpolitik skal en højere grad af bekymring til, før der interveneres i familierne. Til gengæld er baren lavere for anbringelse udenfor hjemmet. Der er også ligheder mellem socialarbejdernes tilgange på tværs af de tre lande. Der er enighed om hvilke risikofaktorer som har betydning i sagerne. Ingen af socialarbejderne prioriterer et ressourceperspektiv. (Skivenes \& Stenberg 2015)

\section{Andre perspektiver}

Skotte peger ud fra sin gennemgang af 16 sager på, at socialarbejderne tager afsæt i teoretiske forståelser i sagerne $\mathrm{fx}$ fra udviklings- og tilknytningsteori, men dette sker implicit uden at teorier og begreber nævnes (Skotte 2020).

Firmin peger i forhold til et arenaperspektiv i en analyse af SCR om alvorlig vold mod unge på at der typisk er fokus på familien i det sociale arbejde, mens arenaer uden for familien nedprioriteres. Hun referer til en unders $\emptyset$ gelse, der viser at i ca. en femtedel af sagerne mishandles de unge af personer, som de ikke er i familie med fx andre unge (Brandon, Sidebotham, Bailey, Belderson, Hawley, Ellis, \& Megson 2012 i Firmin 2018).

Walsh, White, Morris \& Doherty har unders $\varnothing$ gt forskellige lokale myndigheders tilgang via en vignet om en familie med komplekse problemer i 24 fokusgrupper med 108 deltagere (deltagere fra børn- og familie-, misbrugs-, psykiatri- og migrationsområdet). Det første deltagerne kiggede efter i sagen var triggers som indikerede hvilken myndighed, som skulle gå videre med sagen. Undersøgelsen viste også, at socialarbejderens organisatoriske placering påvirker synet på barnet, den unge og familien, idet forskellige afdelinger og organiseringer er præget af forskellige problemfoki, men også af forskellige diskurser om roller og opgaver i en familie, som viser sig materielt i den hjælp familien tilbydes. En specialisering kan derfor resultere i en $\emptyset$ get fragmentering af sociale problemer, som medfører at familier med komplekse problemer skal orientere sig mod forskellige organisatoriske kontekster (Walsh, White, Morris \& Doherty 2018). 
Enell \& Denvall peger i deres unders $\varnothing$ gelse på, at socialarbejderne værdsætter eksperters udsagn, diagnoser og anbefalinger til fremtidige indsatser i konkrete sager, da de ofte er presset af den usikkerhed og uforudsigelighed, der er forbundet med at arbejde med unge på sikrede institutioner. Derfor udvikler socialarbejderne strategier, der kan bidrage til at reducere usikkerhed og det indebærer bl.a. at trækketypisk ureflekteret - på eksperters udsagn og perspektiver (Enell \& Denvall 2017). Skotte har også blik for socialarbejdernes brug af ekspertudtalelser, som hun ser brugt strategisk fx ud fra et $\varnothing$ nske om bevilling af ressourcer (Skotte 2020).

\section{Opsummering}

Opsummerende fremhæver flere af de danske undersøgelser risiko- og ressourceperspektiver som væsentlige faglige perspektiver hos socialarbejderne. En komparativ unders $\varnothing$ gelse mellem Norge, England og USA peger imidlertid på, at socialarbejderne i langt mindre omfang arbejder med et ressourceperspektiv end et risikoperspektiv. Socialarbejderne i de tre lande er stort set enige når der skal udpeges risikofaktorer, men de ser indsatser i lyset af hvilket velfærdsstatssystem som de arbejder under.

\subsubsection{På hvilken måde indgår socialarbejderens personlige perspektiv som en del af analysen?}

\section{Intuition og mavefornemmelser}

Anne Mette Møller når frem til at socialarbejdere bruger intuition og mavefornemmelser i sagsarbejdet, som er vidensformer med tavse og i en eller anden grad personlige elementer. Denne form for viden er bedre udviklet hos erfarne socialarbejdere end hos mindre erfarne (Møller 2018). Flere andre undersøgelser i forskningsoversigten lægger også vægt på individuelle vidensforskelle mellem socialarbejdere af betydning for sagsarbejdet (Skotte 2016, Lushley et al. 2017).

\section{Skøn og handlerum}

Stina Krogh Petersen peger på at socialarbejdernes personlige perspektiv udfolder sig gennem skøn og det handlerum, der er i undersøgelsesprocessen. I kommune A finder hun, at et stort handlerum ikke opfattes som en ubetinget fordel af socialarbejderne, men også som en frihed, der kan bidrage til en vis tilfældighed, faglig ensomhed og stedvis frustration. I kommune B fremhæver socialarbejderne den fælles tilgang med dialogm $\varnothing$ det og det løbende samarbejde med familierne som en mulighed for at gøre sig aktivt gældende som socialarbejder til forskel fra tidligere, hvor socialarbejderne 'stod udenfor og kiggede ind' på sagen (Petersen 2017; 178). Solem, Diaz \& Hill anbefaler i tråd med dette at bruge faglige værktøjer for at kvalificere socialarbejdernes individuelle og normative vurderinger ud fra deres SCR analyse af sager om alvorlige omsorgssvigt (Solem, Diaz \& Hill 2019). Ud fra en specifik vinkel på skriftlighed i socialt arbejde, fremhæver Skotte det handlerum der er fra det, hun betegner som en sags virkelige drama til de forhold, som socialarbejderen noterer eller ikke-noterer i sagsakterne (Skotte 2020).

Heggdalsvik, Rød \& Heggen finder i deres fokusgruppeinterviews, at de socialarbejdere, som udelukkende arbejder skønsbaseret, oftere trækker på deres følelser og erfaringer end socialarbejdere der bruger Kvelloskabeloner (Heggdalsvik, Rød \& Heggen 2018).

Skotte har i en undersøgelse prospektivt fulgt sag i Norge med nyfødte tvillinger i en familie, hvor socialforvaltningen balancerede mellem en familieindsats og en anbringelse igennem et år. Sagen skiftede mellem tre socialarbejdere i forvaltningen, og ved hvert skift havde den nye socialarbejder en oplevelse af at det var nødvendigt at unders $\varnothing$ ge sagen igen og danne sin egen forståelse. Skotte er kritisk overfor det samlede forl $\emptyset \mathrm{b}$, men betoner at hun opfatter at socialarbejderne er personligt engagerede og ansvarlige i forhold til sagens handlerum (Skotte 2016). Unders $\varnothing$ gelsen er særlig interessant fordi den følger et forløb real-time og har en mere direkte adgang til sagsarbejdet end retrospektive unders $\emptyset$ gelser. 


\section{Kynisme}

Kettle \& Jackson lægger vægt på, at socialarbejderne skal bevare en passende distance til de familier, de arbejder med for at kunne bevare et professionelt perspektiv på sagen. Hvis relationen bliver for tæt, er der en risiko for, at socialarbejderen overser nøgleinformation. De anfører i den forbindelse, at kynisme kan være brugbart i socialt arbejde i det omfang, at socialarbejderen bruger den til at være opmærksom på familiens mulighed for bedrag og manipulation. De advarer dog om, at kynisme kan tage overhånd og anbefaler en tilgang præget af respektfuld usikkerhed (Kettle \& Jackson 2017; 1634-1635). Kettle fremhæver som tidligere nævnt også socialarbejderens indre verden som en af flere faktorer, som fører frem til vendepunkter i SCR-børne- og ungesager (Kettle 2017).

\section{Opsummering}

Opsummerende om socialarbejdernes personlige perspektiv peger Stina Krogh Petersen på at det udfolder sig gennem skøn og det handlerum, der er i undersøgelsesprocessen. Et stort handlerum opfattes imidlertid ikke som en ubetinget fordel af socialarbejderne, men kan også give en vis tilfældighed, faglig ensomhed og stedvis frustration. Anne Mette Møller peger på at socialarbejdernes personlige perspektiv er en del af det sociale arbejde via den tavse viden, der indgår i både propositionel, proceduremæssig og viden om personer. Denne viden opleves som intuition og mavefornemmelser og er bedre udviklet hos erfarne socialarbejdere end nyuddannede.

\section{Konklusion \& perspektivering}

Unders $\emptyset$ gelsesspørgsmålet for forskningsoversigten er på hvilken måde socialarbejdere arbejder med socialfaglig analyse igennem processer, vidensformer og perspektiver i børne- og ungesager. Nedenfor vil vi konkludere og perspektivere på forskningsoversigtens svar på spørgsmålet.

Både danske, norske, svenske og engelske undersøgelser peger på at socialfaglig analyse og beslutninger udfolder sig som løbende processer igennem sagsforløb fremfor i særligt afgrænsede dele af sagsforløbet. Dvs. socialfaglig analyse er ikke alene bundet til den børnefaglige undersøgelse, men en løbende aktivitet igennem sagsforløb. Forskningsoversigten lægger sig dermed op ad Socialministeriets forståelse af pejlemærket 'Faglig udredning' som udtryk for kvalitet i sagsbehandlingen.

Den opmærksomhed som findes i danske lærebøger og undervisningsmaterialer på processer som opdelt i først indsamling af viden i den konkrete sag, beskrivelsesfasen, så kobling af den specifikke viden med generel viden i analysefasen, inden socialarbejderen udformer en samlet risikovurdering afspejler sig ikke i forskningsoversigtens undersøgelser. En forklaring på dette kan være at der arbejdes med et professionsideal i undervisningen på danske videreuddannelser, som ikke har klangbund i den aktuelle professionspraksis.

Der er enighed mellem forskere fra Norden og Storbritannien om at anbefale to komplementære spor $\mathrm{i}$ børne- og ungesager: professionelle skøn kombineret med fælles tilgange i form af standardiserede metoder og redskaber. Hvor arbejdet med skøn kan ses som en professionstilgang, der bygger på viden, holdninger og etik, kan metoder og redskaber ses som en operationel tilgang. Med en metafor er fælles metoder og redskaber skelettet, mens de professionelles skøn er de arbejdende muskler i analysearbejdet. Forskningsoversigten tyder på nationale forskelle i vægtningen mellem skøn og standardiserede metoder og værktøjer i sagsarbejdet, som hænger sammen med type af velfærdsstatssystem. I Norden, særligt Norge, lader der til at være en praksis for at skønne mere i sagsarbejdet end i de angelsaksiske lande, hvor balancen er rykket mod standardiserede metoder og redskaber. 
En del af den danske debat om børne- og ungearbejdet har været præget af en skepsis overfor brug af standardiserede metoder og værktøjer. Forskningsoversigten peger imidlertid på at der kan være væsentlige fordele ved fælles standarder. Først og fremmest er fælles standarder udgangspunkt for en udfoldelse af systematik i sagsarbejdet. Derudover kan fælles redskaber ifølge engelske unders $\varnothing$ gelser spille en central rolle i børne- og ungesager om omsorgssvigt, som kan være svært at indfange til forskel fra vold og misbrug. Endelig peger andre engelske undersøgelser på at fælles, landsdækkende redskaber kan være en korrektion til den tendens til normalisering af svære vilkår, som kan ske blandt socialarbejdere i områder med mange socialt udsatte familier. Men en stigende ulighed er dette perspektiv relevant også i en dansk sammenhæng.

Det kan i denne optik ses som et problem, at socialarbejdere ser ud til at benytte fælles metoder og redskaber i mindre grad end tiltænkt og at implementeringen ikke er tilstrækkelig grundig og omfattende.

En anden forskel på danske lærebøger og forskningsoversigten er diskussionen om hvorvidt opgaven med socialfaglig analyse og skøn er knyttet til individuelle eller kollektive processer i sagsarbejdet. Diskussion om kollektive samarbejdsprocesser er langt mere fremtrædende $\mathrm{i}$ forskningsoversigten end $\mathrm{i}$

undervisningsmaterialet. De fleste unders $\emptyset$ gelser i forskningsoversigten ser kollektive samarbejdsprocesser som en kvalificering af sagsarbejdet igennem fælles, intersubjektive vurderinger fremfor individuelle opfattelser, som kan være præget af tilfældigheder og personlige ubearbejdede forhold.

Kombinationen af kollektive arbejdsprocesser og en fælles tilgang problematiseres på den måde at der kan ske en glidning i retning organisatoriske og politiske prioriteringer, og at der ikke gives tilstrækkelig plads til ny viden og holdninger, som falder uden for de organisatorisk sanktionerede socialfaglige tilgange.

Det ser ud til at kommunens og afdelingens størrelse kan spille en rolle i spørgsmålet om individuelle eller kollektive arbejdsprocesser, således at større kommuner er mere tilbøjelige til at organisere kollektive arbejdsprocesser end mindre kommuner. Der er dog ikke tale om en lineær sammenhæng.

Fra et forældreperspektiv er det interessant at der er indikationer på inddragelsen lykkes bedst i kommuner med en fælles tilgang fremfor i kommuner med st $\varnothing$ rre metodefrihed, da en fælles tilgang skaber en større grad af gennemsigtighed i sagsarbejdet.

Et bud på hvorfor der i forskningsoversigtens undersøgelser er en større optagethed af kollektive samarbejdsprocesser end $\mathrm{i}$ undervisningsmaterialet kan være, at undervisningsmaterialet som tidligere nævnt ikke i særlig høj grad baserer sig på forskning. Referencerammen i en del af det unders $\varnothing$ gte undervisningsmateriale lader til at være en professionspraksis, som er mindre udbredt end tidligere, da der de sidste ca. 20 år har været en udvikling fra metodefrihed hos den enkelte socialarbejder mod brug af fælles metoder. De faglige og organisatoriske konsekvenser af dette skift er kun i begrænset omgang indfanget i de lærebøger mv., som vi har unders $\emptyset$ gt, og det er en ændring som med fordel kan gives opmærksomhed i kommende lærebogsudgivelser.

Forskningsoversigten kan på dette grundlag pege på vigtige mellemregninger som ser ud til at blive udeladt eller nedtonet i socialfaglige analyser: For det første betydningen af at eksplicittere den sociale kontekst for borgerens livsverden og for det andet en italesættelse af socialarbejderens handlemuligheder overfor børn, unge og familier. I sagsarbejdet kan et fokus på konteksten for borgerens livsverden bl.a. aktiveres gennem 
brug af fælles standarder. Sådanne standarder kan være en vej til at synliggøre særlige forhold i familier og netværk bl.a. i forhold til omsorgssvigt og i lokalområder fx fattigdom. Et fokus på italesættelse af handlemuligheder i børne- og ungesager er især relevant, fordi gennemsigtighed om sagsprocesser og handlemuligheder giver familier og netværk bedre deltagelsesmuligheder.

Der er forskellige kategoriseringer af viden i forskningsoversigtens unders $\emptyset$ gelser, hvor det samlende er en opdeling i analytiske og intuitive vidensformer, hvor sidstnævnte lader til at være bedre udviklet hos erfarne socialarbejdere end hos nyuddannede. Nyere dansk forskning peger på at professionspraksis ikke alene kan baseres på intuitiv viden, da der i stigende grad er forventning om en eksplicit form for professionalisme. I store danske kommuner som er spydspidser i vidensarbejdet er der sket en forskydning af ansvaret for at mobilisere ny viden fra den enkelte socialarbejder til organisationen. I Danmark er et vigtigt faglig perspektiv risiko- og beskyttelsesfaktorer, hvilket kan hænge sammen med at det er et centralt perspektiv i ICS, som bruges som fælles tilgang i størstedelen af landets 98 kommuner.

Når det gælder forældrenes inddragelse i sagerne, peger unders $\varnothing$ gelserne i forskningsoversigten på, at den varierer afhængig af den enkelte socialarbejder og at forældrenes rolle snarere er som informanter end som dialogpartnere. Med andre ord bidrager forældrene til beskrivelser men ikke til refleksionsprocesser i børne- og ungesager. Et direkte børne- og ungeperspektiv er fraværende i forskningsoversigtens unders $\varnothing$ gelser, hvor børn og unges synspunkter udelukkende er gengivet via stedfortrædende aktører.

Det skal tilføjes, at vi i forskningsoversigten har kigget efter definerende elementer i socialfaglig analyse ud fra operationaliseringen i notatet om socialfaglig analyse. Det betyder at vi især har haft blik for socialfaglig analyse som et sæt af elementer i form af processer, vidensformer og perspektiver retrospektivt i sagsforløb. Komplementært kunne det være interessant at arbejde videre med et egentligt procesperspektiv, hvor børne- og ungesager sager følges prospektivt.

Afslutningsvist vil vi foreslå at vi fremover overvejer at italesætte 'socialfaglig analyse' som 'refleksions- og beslutningsprocesser' i sagsarbejdet. Refleksions- og beslutningsprocesser peger på mere dynamiske og åbne processer end socialfaglige analyser, ligesom man kan argumentere for at det er det er lettere at invitere børn, unge og familier ind og bidrage til refleksions- og beslutningsprocesser end i socialfaglige analyser. Endelig skabes der med begrebet refleksions- og beslutningsprocesser en direkte vej til forskningen om beslutningsprocesser.

\section{Referencer}

Andersen, Lotte, Katrin Leicht Schnohr \& Annemette Matthiessen (2021): Trænger vi til at forstå den sociale analyse på en anden måde? Uden for Nummer, årg. 20, nr. 43; 4-15.

Ankestyrelsen, principafgørelse nr. 159-12, j.nr. 43000-27-12, 15.820212.

Bengtsson, Tea Torbenfeldt \& Rikke Fuglsang Olsen (2021): Kortlægning af viden om kvalitet $i$ sagsbehandlingen på børne- og ungeområdet - et litteraturstudie af danske publikationer. VIVE.

Bjerre, Line Søberg (2017): Fortællinger om og konstruktioner af børn i socialt myndighedsarbejde, ph.d. Aalborg Universitet. 
Carnichan, Sarah, Erica Weissinger, Colleen Henry, Nicole Liner-Jigamian \& Michael J. Austin (2018): Using qualitative data-mining to identify skillfull practice in child welfare case records. Journal of Public Child Welfare, Vol. 13, Issue 4; 419-440.

De aldersopdelte fokusområder - et redskab til arbejdet med ICS, Socialstyrelsen, 2018.

Enell, Sofia \& Verner Denvall (2017): Searching for the right track - managing care trajectories in child welfare. Child \& Family Social Work, Vol. 22, Issue 1; 398-408.

Esping-Andersen, Göran (1990): The three worlds of welfare capitalism. Princeton: Princeton University Press, 1. ed.

Firmin, Carlene (2018): Contextualizing case reviews: A methodology for developing systemic safeguarding practices. Child \& Family Social Work, Vol. 23, Issue 1; 45-52

Forrester, Donald (2017): Outcomes in Children's Social Care. Journal of Children's Services, Vol. 12, Issue 2; 144-157.

Heggdalsvik, Inger Kristin, Per Arne Rød \& Kåre Heggen (2018): Decision-making in child welfare services: Professional discretion versus standardized templates. Child \& Family Social Work, Issue 3; 522-529.

Helm, Duncan \& Autumn Roesch-Marsh (2016): The Ecology of Judgement: A Model for Understanding and Improving Social Work Judgement. British Journal of Social Work, 47; 1361-1376.

Holmgren, Anette (2010): Fra terapi til pædagogik. Hans Reitzels Forlag.

Holt, Kim \& Nancy Kelly (2013): Why Parents matter; exploring the impact of a hegemonic concern with the timetable for children. Child \& Family Social Work, Vol 21, Issue 2; 156-165.

Hood, Rick (2014): How Professionals Experience Complexity: An Interpretative Phenomenological Analysis. Child Abuse Review, Vol. 24; 140-152.

Kildedal, Karin, Lars Uggerh $\varnothing$, Sigrid Nordstoga \& Solveig Sagatun (2010): Den børnefaglige unders $\varnothing$ gelse på vej mod handleplanen. Uden for Nummer, årg. 11. nr. 21; 4-17.

Kettle, Martin (2017): Revisiting the Rule of Optimism. British Journal of Social Work, Vol. 47, Issue 6; 16241640.

Kettle, Martin (2017): The tipping point: fateful moments in child protection. Child \& Family Social Work, Vol 22; 31-39

Kongsgaard, Leif (2014): Multiteoretisk praksis i socialt arbejde. Frederiksberg: Samfundslitteratur, 1. udgave.

Kvalitet i sagsbehandlingen - en håndbog i anvendelse af ICS og udredningsværktøjet, Socialstyrelsen, 2018.

Lucas, Steven (2019): The assembly of active participation by parents of children subject to a multi-agency model of early intervention on child and family services. Child \& Family Social Work, Vol. 24; 529-536.

Lushey, Clare J., Jane Barlow, Gwynne Rayns \& Harriet Wras (2017): Assessing Parental Capacity when there are Concerns about an Unborn Child: Pre-Birth Assessment Guidance and Practice in England. Child Abuse Review, Vol. 27; 97-107. 
Matthiessen, Annemette, Birgitte Zeeberg \& Maja Haack (2017): Specialisering - et tveægget sværd? Professionshøjskolen Metropol.

Meysen, Thomas \& Liz Kelly (2018): Child protection systems between professional cooperation and trustful relationships: A comparison of professional practice and ethical dilemmas in England/Wales, Germany, Portugal and Slovenia. Child \& Family Social Work, Vol. 23, Issue 2; 222-231.

Moesby-Jensen, Cecilie \& Helle Schjellerup Nielsen (2013): Praksiserfaringer med to socialfaglige metoder. I Lihme (Red.): Socialt arbejde med udsatte unge. København: Akademisk forlag.

Morris, Kate, Will Mason, Paul Bywaters, Brid Featherstone, Brigid Daniel, Geraldine Brady, Lisa Bunting, Jade Hooper, Nughamana Mirza, Janathan Scourfiled \& Calum Webb (2018): Social work, poverty, and child welfare interventions. Child \& Family Social Work, Vol. 23, Issue 3; 364-372.

Møller, Anne Mette (2018): Organizing knowledge and decision-making in street-level professional practice. A practice-based study of Danish child protective services.

Ph.D. afhandling, Københavns Universitet, Institut for Statskundskab.

Nielsen, Helle Schjellerup (2011): Udsatte børn I skolelivet og på andre sociale arenaer. I Bo, Guldager \& Zeeberg (red.) Udsatte børn - et helhedsperspektiv. København, Akademisk Forlag, 2. udg.; 128-161.

Nyathi, Nhlanganiso (2018): Child protection decision-making: Social workers' perceptions. Journal of Social Work Practice, Vol. 32, Issue 2; 189-203.

Olesen, Peter, Leena Eskelinen \& Dorte Caswell (2005): Faglighed i socialt arbejde som forskningsgenstand - et kritisk-konstruktivt perspektiv, AKF.

Petersen, Stina Krogh (2017): At undersøge og blive unders $\varnothing$ gt. Et kvalitativt casestudie af hvordan professionel praksis i den børnefaglige undersøgelse udfoldes og opleves i tre kommunale myndighedsafdelinger. Ph.d. afhandling, Aalborg Universitet, Institut for Sociologi og Socialt Arbejde.

Popay, Jennie, Helen Roberts, Amanda Sowden, Mark Petticrew, Lisa Arai, Mark Rodgers, Nicky Britten, Katrina Roen \& Steven Duffy (2006): Guidance on the conduct of narrative synthesis in systematic reviews. A Product from the ESRC Methods Programme, ResearchGate, 1. April.

Schnohr, Katrin Leicht, Lotte Andersen \& Annemette Matthiessen (2020): Hvad er socialfaglig analyse? svar fra et uddannelsesperspektiv, Københavns Professionshøjskole.

Skivenes, Margit \& Hanne Stenberg (2015): Risk Assessment and domestic violence - how do child welfare workers in there countries assess and substantiate the risk level of a 5 -year-old girl? Child \& Family Social Work, Vol. 20, Issue 4; 424-236

Skotte, Pernille Stornæss (2016): Colligation in child welfare work: Decision-making in the case on the tipping point. Qualitative Social Work, vol. 17; 115-132.

Skotte, Pernille Stornæss (2020): On caseworkers writing in child welfare - when less is more. European Journal of Social Work, Vol. 23, Issue 1; 131-143. 
Solem, Linda, Clive Diaz \& Lauren Hill (2019): A study of serious case reviews between 2016 and 2018: What are the key barriers for social workers in identifying and responding to child neglect? Journal of Children's Services, Vol. 15, Issue 1; 1-14.

Spratt, Trevor, John Devaney \& John Frederick (2019): Adverse Childhood Experiences: Beyond Signs of Safety; Reimagining the Organisation and Practice of Social Work with Children and Families. British Journal of Social Work, Vol 49, Issue 8; 2042-2058.

Sørensen, Kresta M. (2016a): Metoder til den børnefaglige undersøgelse i komparativt perspektiv, kappe, Aalborg Universitet.

Sørensen, Kresta M. (2016b): Skemaernes betydning for den børnefaglige unders $\varnothing$ gelse. Fontene Forskning, nr. 2. årgang 9; 4-15.

Sørensen, Kresta M. (2016c): Vidensdeling med henblik på faglig udvikling. Uden for Nummer, nr. 33; 3546.

Sørensen, Kresta M. (2018): A Comparative Study of the Use of Different Risk-Assessment Models in Danish Municipalities. British Journal of Social Work, vol. 48, Issue 1: 195-214.

Turney, Danielle \& Gillian Ruch (2018): What makes it so hard to look and listen? Exploring the use of the Cognitive and Effective Supervisory Approach with children's social managers. Journal of Social Work Practice, Vol. 32, Issue 2; 125-138.

Walsh, Julie, Sue White, Kate Morris \& Paula Doherty (2018): How do you solve a problem like Maria? Family complexity and institutional complications in UK social work. European Journal of Social Work, Vol. 22, Issue 6; 1050-1061.

Warming, Hanne (2011): Børneperspektiver - børn som ligeværdige medspillere i socialt og pædagogisk arbejde. København: Akademisk Forlag. 